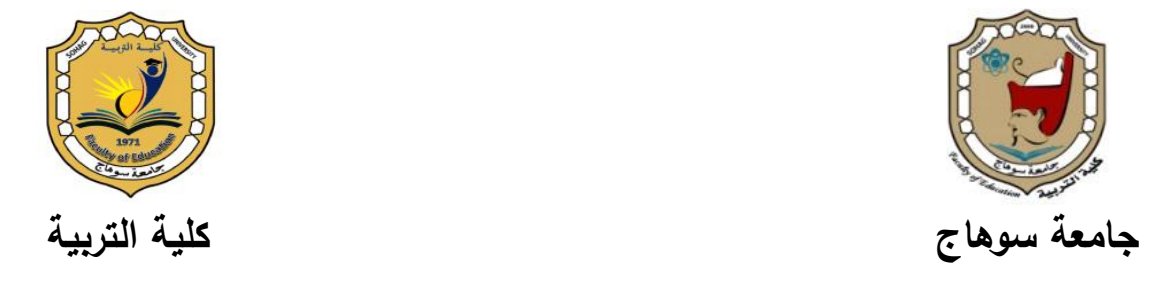

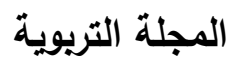

فاعلية استخدام استزاتيجية الإثارة العشهائية في تدريس القراءة لتنـمية الثروة اللغوية والخيال الإبداعي لدى تلاميذ المرحلة الابتدائية الأزهرية

\author{
إعداد \\ د/ هيام عبدالعال محمدل إبراهيم مرعي \\ مدرس المناهج وطرائق تدريس اللغة العربية والعلوم الثرعية \\ كلية الدراسات الإنسانية بالدقهلية جامعة الأزهر
}

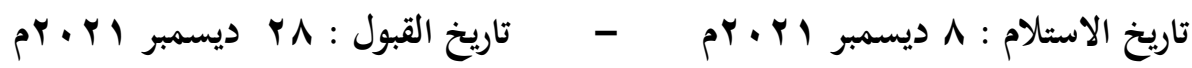

DOI: 10.12816/EDUSOHAG.2021. 


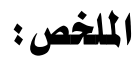

هدف البحث الحالي التعرف على فاعلية استخدام استراتيجية الإثارة العثوائية في تدريس القراءة لتنمية الثروة اللغوية والخيال الإبداعي لدى تلاميذ المرحلة الابتدائية الأزهرية؛ ولتحقيق الهدف من البحث أعدت الباحثة أدوات البحث متضمنة (اختبار الثروة اللغوية،

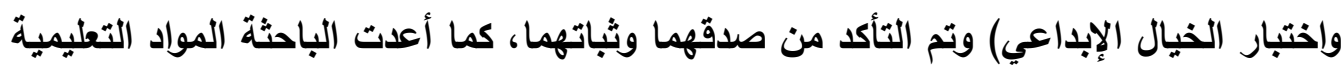
للبحث متضمنة (دليل المعلم وأوراق عمل التلميذ وفق استراتيجية الإثارة العشوائية). وطبقت التجربة على عينة من تلاميذ الصف الخامس الابتدائي الأزهري بمعه شبرا

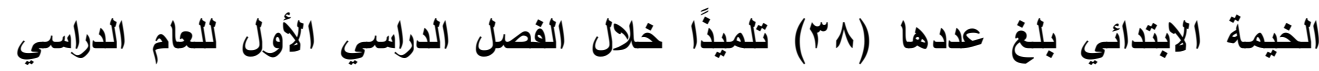

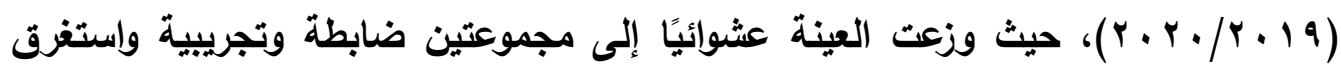

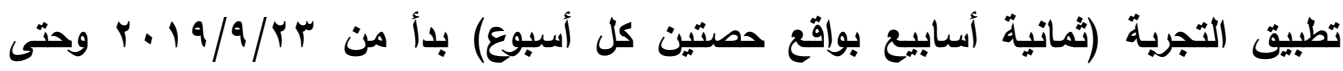
$. r \cdot 19 / 11 / 1 \varepsilon$

وقد أظهرت النتائج وجود فروق ذات دلالة إحصائية في اختبار الثروة اللغوية لصالح المجموعة التجريبية، وكذلك وجود فروق ذات دلالة إحصائية في اختبار الخيال الإبداعي لصالح المجموعة التجريبية. ويناءً على نتائج البحث أوصت الباحثة بضرورة توظيف استراتيجية الإثارة العشوائية في تدريس اللغة العربية، وتدريب المعلمين على إجراءاتها، وإجراء المزيد من الدراسات والأبحاث التي تتناول هذه الاستراتيجية مع متغيرات دراسية أخرى. الكلمات المفتاحية: استراتيجية الإثارة العشوائية- الثروة اللغوية- الخيال الإبداعيتلاميذ المرحلة الابتدائية الأزهرية. 
The effectiveness of using the random excitement strategy in teaching reading for developing linguistic wealth and creative imagination among $\mathrm{Al}$ Azhar primary school students

\begin{abstract}
:
The main objective of the current research is to identify the effectiveness of using the random excitement strategy in teaching reading for developing linguistic wealth and creative imagination among Al-Azhar primary school students. Educational research included (teacher's guide and student worksheets according to the random agitation strategy).

The experiment was applied to a sample of the fifth grade of Al-Azhar primary school at Shubra El-Kheima Primary Institute, which numbered (38) students during the first semester of the academic year (2019/2020), where the sample was randomly distributed into two control and experimental groups. It started from 23/9/2019 to 14/11/201

The results showed that there were statistically significant differences in the language wealth test in favor of the experimental group, as well as statistically significant differences in the creative imagination test in favor of the experimental group.

Based on the results of the research, the researcher recommended the necessity of employing the random excitement strategy in teaching Arabic, training teachers on its procedures, and conducting more studies and research that deal with this strategy with other study variables.
\end{abstract}

Keywords:Random excitement strategy-, linguistic wealth- creative imagination- Al-Azhar primary school students. 


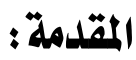

شهر عصر العولمة تحديات كثيرة في مختلف الأنظمة ومنها التعليم، ومن أبرز تلك التحديات إعداد مواطن عصري متقتح الذهن لديه الحافز والقدرة على الخيال والإبداع، ويتميز بمواصفات عصرية تمكنه من التعبير عن حاجاته ورغباته وأحاسيسه ومواقفه في ظل هذه المتغيرات المتسارعة بفاعلية ووعي في محاولة لفهم معطيات الحاضر والتكيف معها، ومن ثم التهيؤ لتحديات المستقبل. وتعد اللغة من أرقى وسائل التعبير لدى الإنسان، وأداة الاتصال المثلى في حياة البشر ؛ فمها بلغ ما يحصله الإنسان من مظاهر حضارية من علوم ومعارف وطرق ووسائل

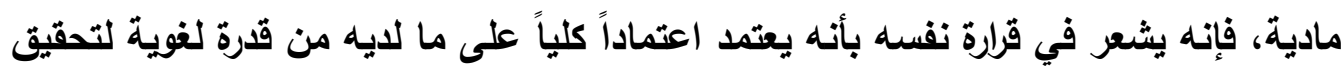
مآربه.

ويعد ثراء المفردات اللغوية عاملًا مهمًا في تنيمة الخيال لدى التلاميذ وتكمن أهمية الخيال في كونه أساس الإبداع والتطور الإنساني؛ فهو يجسِّ القدرة على الإبداع والابتكار،

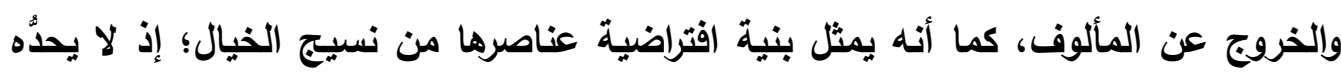
معُلَمَ كوني، ولا معرفة مدودة؛ بل ينطلق أبعد من هذا كله باحثًا عن التطور والتقدم، فهو

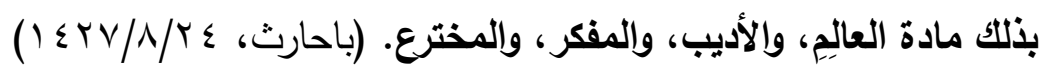

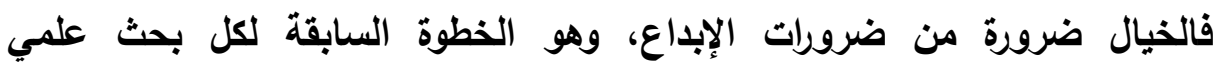
واجتماعي؛ هذا وقد أثبتت الدراسات التي تناولت العلاقة بين الإبداع والخيال أن الخيال في الإبداع حقيقة الأمر عنصر أساسي وفعال في منظومة التفكير والنشاط العقلي، ويرهنت هذه الدراسات

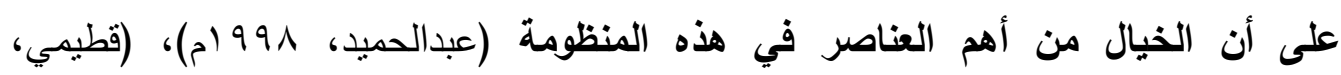

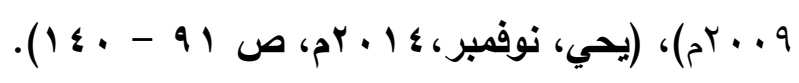

ويعد الخيال الإبداعي من أهم الموضوعات التي يحرص عليها التريويون في العملية

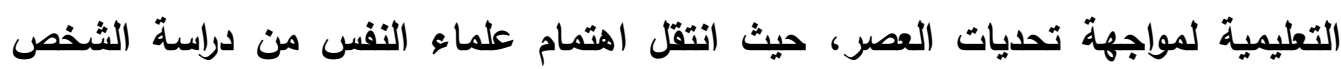

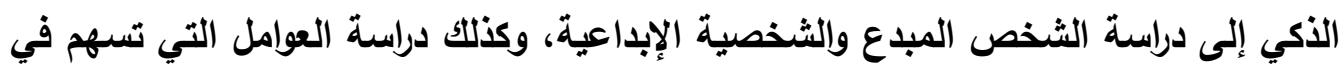

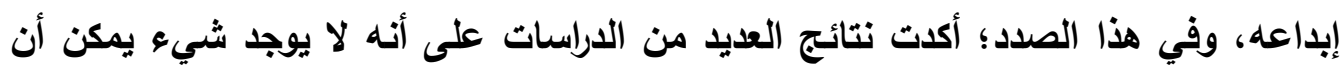
يسهم في رفع مستوى رفاهية وتطور الإنسانية وتقدمها أكثر من رفع مستوى الأداء الإبداعي

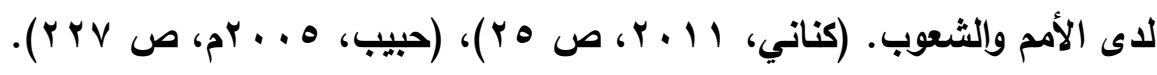


فمهارات الخيال الإبداعي تعد أمرًا مهمًا وضروريًا في جميع المراحل التعليمية، وهي

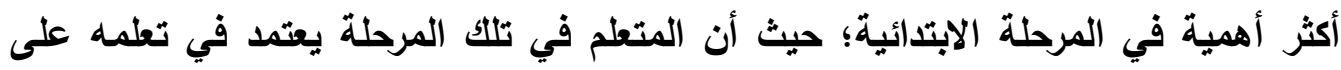
الإحساس والخيال والخبرة بلرجة كبيرة، وهو الأمر الذي يتطلب استخدام الأنشطة واستراتيجيات التدريس التى تعرض المحتوى بصورة تطلق خيال المتعلم لروئة كل ما هو جديد؛ كما أن النشاط الخيالي عند الطقل يتخذ اتجاهًا جديدًا ابتداءً من سن السادسة نتيجة

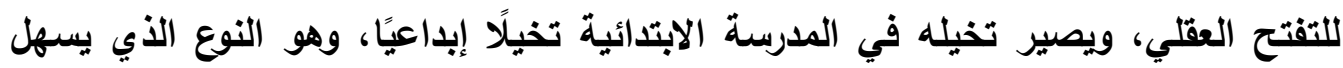
توجيهه وتنميته في مثل هذا السن ثم يأخذ في الاضمحلال ابتداء من سن التاسعة أو العاشرة إذا لم ندركه بالرعاية والتدريب والإثراء. وهذا يتطلب العناية والاهتمام بتوفير بيئة تعليمية مناسبة تثير خيال المتعلم وتسعى إلى تنميته من خلال المحتوى الدراسي ويالاستعانة بمداخل

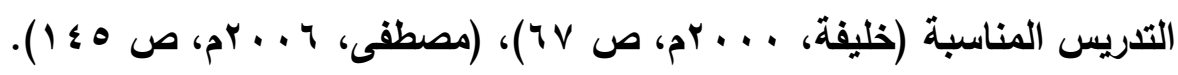
ويالرغم من تلك الأهمية فإن العديد من الدراسات أثارت إلى أن مناهج اللغة العربية لا ثُنمي الخيال والإبداع عند الطلاب، وأوصت بضرورة إعادة النظر في مناهج اللغة العربية بفروعها المختلفة بحيث تشتمل على مثيرات تدفع الطلاب نحو التفكير وصولاً للإبداع المنشود، وضرورة استخدام استراتيجيات تلريسية تساعد على تنمية الخيال الإبداعي تترجم

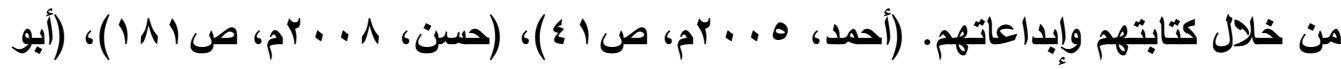

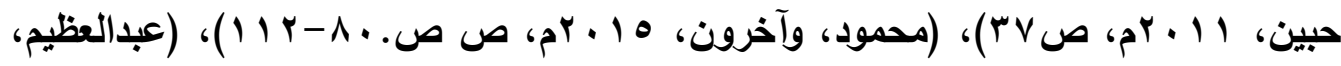

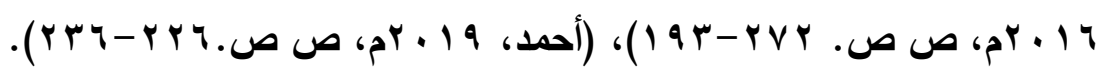
ومن الاستراتيجيات التي يمكن أن تسهم في تنمية الثروة اللغوية والخيال الإبداعي استراتيجية الإثارة العشوائية؛ حيث أنها آلية من آليات التفكير الإبداعي تقوم على استثارة

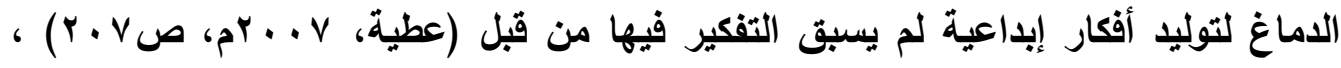
فتوفر تلك الاستراتيجية للطالب حرية ومرونة وتقريه من الإبداع وذلك من خلال إجراء مقارنات بين مفردات لا تربطها علاقات واضحة، إذ يشعر التلميذ عن طريق تأمله للمفردات

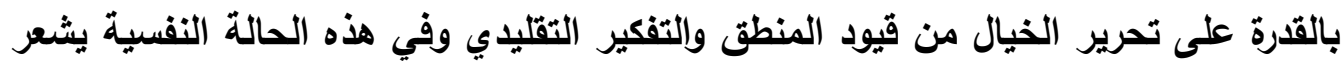

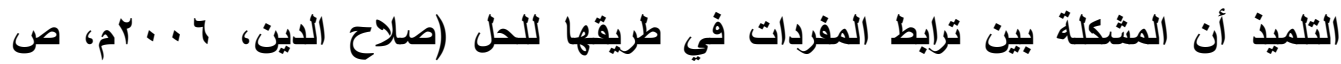
.$(\leqslant)$ Y 
وقد نالت استراتيجية الإثارة العشوائية اهتمام الباحثين فاستخدمت دراسة (محمد،

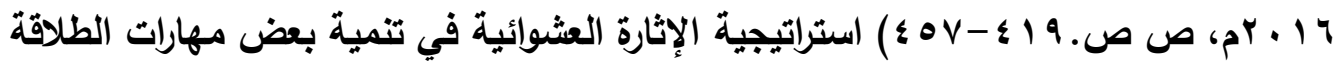

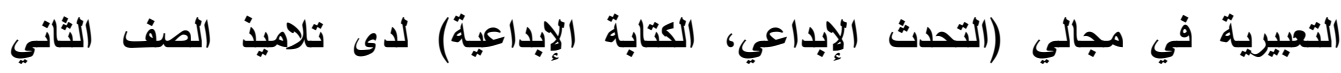

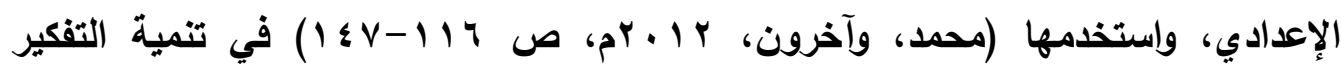
الإبداعي والذكاء الوجداني لدى طلبة الصف الأول المتوسط في الفيزياء واستخدمتها

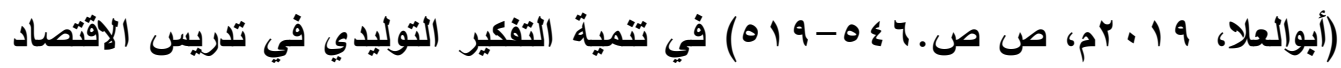

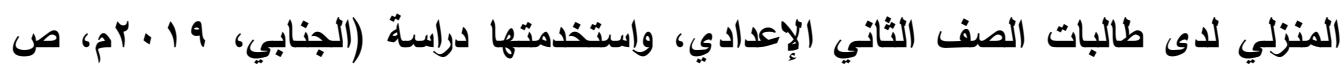

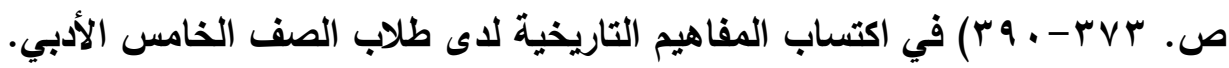
ويناءً على ذلك، وانطلاقاً من أن الهدف الرئيس للتربية الحديثة هو الانتقال من التعليم التقليدي إلى التعليم من أجل التفكير، والانتقال من تعلم محتوى إلى تعلم مهارات، ودعوة العديد من التريويين بضرورة إعادة بناء المناهج واستخذام استراتيجيات تعليم وتعلم تمدنا بآفاق واسعة تساعد في إثراء اللفة وتتمية المهارات العقلية المختلفة؛ لذلك ترى الباحثة هذا البحث مساهمة في تطوير طرق تدريس اللغة العربية من جاتب، وتنمية الثروة اللغوية والخيال الإبداعي من جاتب آخر.

\section{الإحساس بالمشكلة:}

المتأمل للواقع الفعلي لتدريس اللغة العربية في المرحلة الابتدائية الأزهرية يلاحظ أنه يعاني من مشكلات تتمثل في افتقار التلاميذ إلى الثروة اللغوية اللازمة لهم، وكذلك مهارات الخيال الإبداعي، ولعل من أهم أسباب ذلك اعتماد معظم معلمي اللغة العربية على الطرق التقليدية العامة في التدريس، وقد نبع الاحساس بالمشكلة من خلال: ما لمسته الباحثة أثناء الإشراف على التربية العملية بالمعاهد الأزهرية من تدني مستوى التلاميذ في الثروة اللغوية ومهارات التفكير والخيال. وللتأكد من الإحساس بالمشكلة قامت الباحثة بإجراء المقابلات الشخصية لاستطلاع الآراء وقد شملت عدد ( • (1) من معلمي ومعلمات اللغة العربية للمرحلة الابتائية الأزهرية، وكان السؤال الرئيسي في هذه المقابلات

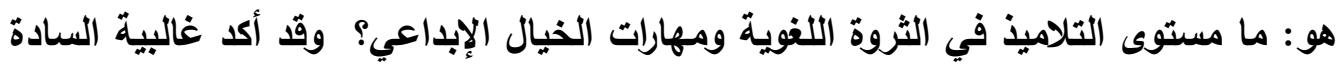
المعلمين على وجود ضعف في مستوى التلاميذ في مهارات اللغة عامة وتلك المهارات 
كما أكلت البحوث والدراسات السابقة على هذا الضعف؛ فأكدت دراسة كل من:

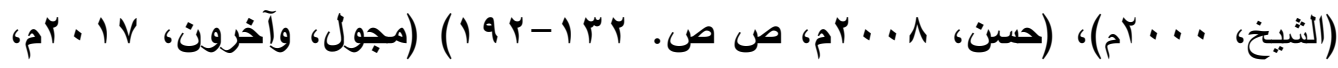

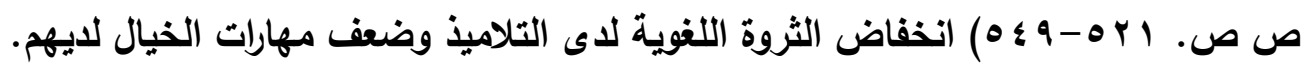
وقد أدرك الباحثون والمختصون والقائمون على التعليم خطورة هذا الضعف؛ فقدمت

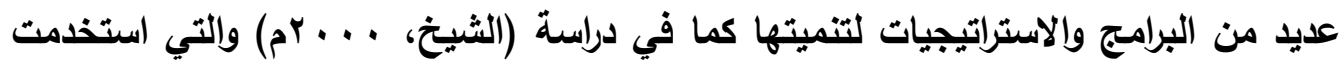
السجع والجناس والوزن لتنمية الثروة اللغوية والتعبير الإبداعي لاى تلاميذ الصف الخامس

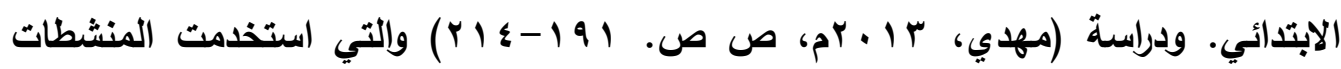
العقلية في تتمة الثروة اللغوية لاى تلاميذ الصف الرابع الابتائي في التعبير التحريري.

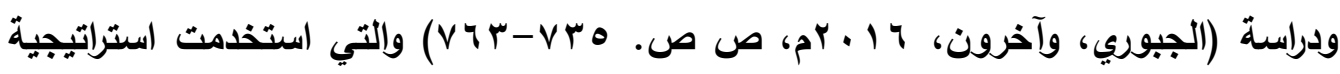
إلماعات السياق في تنمية الثروة اللفوية لدى طلاب الصف الخامس الأدبي في مادة الأدب والنصوص.

وأوصت هذه الدراسات بضرورة تنمية الثروة اللغوية للمتعلمين، وضرورة استخدام استراتيجيات حديثة تحفز من سلوكهم وتثير دوافعهم، ولذا ارتأت الباحثة مساهمة هذا البحث في تنمية الثروة اللغوية ومهارات الخيال الإبداعي، وذلك بهدف تحقيق الهذف المنشود وهو الارتقاء بالعملية التربوية والتعليمية.

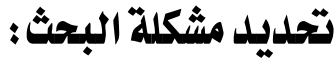

بناءً على ما سبق يمكن تحديد مشكلة البحث في إهمال مادة اللغة العربية لتنمية

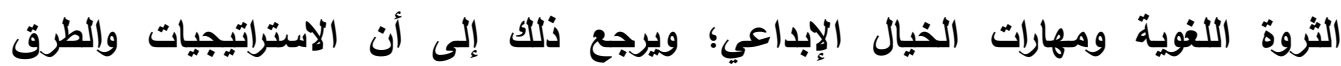
المستخدمة في مادة اللغة العربية لا تساعد على تنمية هذه المهارات، مما أدى إلى ضعف الإسي التلاميذ في الحصيلة اللغوية والخيال الإبداعي؛ مما دعى إلى ضرورة استخدام استراتيجيات تدريس تساعد على تنمية تلك المهارات لاى تلاميذ الصف الخامس الابتدائي، وفي محاولة للتصدي لهذه المشكلة ينطلق البحث من السؤال الرئيس الآتي:

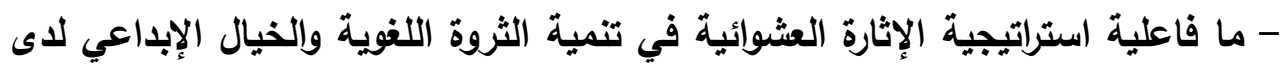
تلاميذ الصف الخامس الابتدائي الأزهري؟ ويتفرع عن هذا السؤال الرئيس الأسئلة الآتية: 1- ما المفردات اللغوية المناسبة لتلاميذ الصف الخامس الابتدائي الأزهري؟ 
r - ما مهارات الخيال الإبداعي المناسبة لتلاميذ الصف الخامس الابتدائي الأزهري؟

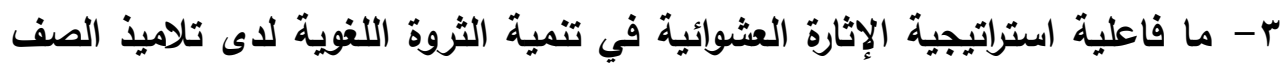

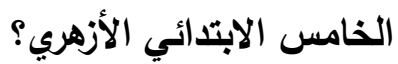
ع - ما فاعلية استراتيجية الإثارة العشوائية في تنمية مهارات الخيال الإبداعي لدى تلاميذ الصف الخامس الابتدائي الأزهري؟

$$
\text { حدود البحث: }
$$

- المفردات اللغوية المتضمنة في موضوعات القراءة التي يتم تدريسها بمادة اللغة العربية لتلاميذ الصف الخامس الابتدائي الأزهري بالفصل الدراسي الأول. - عينة من تلاميذ الصف الخامس الابتدائي الأزهري؛ حيث أنها من أنسب المراحل لتنمية الخيال الإبداعي. باعتبار أن الأطفال قد تعدوا مرحلة الطفولة المبكرة، التي يتميز فيها

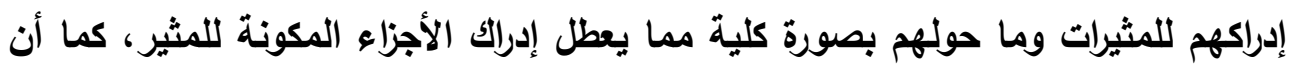
الطقل في هذه السن يتضح اهتمامه بموضوعات جديدة ويزداد حبه للاستطلاع ويكثر من التساؤل ويتميز بسرعة نمو تخيله وشدة تطلعه للآفاق بعيدة المدى، وتستهويه المخاطرة

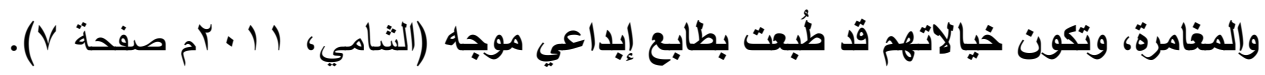
- مهارات الطلاقة والمرونة والأصالة والحيوية من مهارات الخيال الإبداعي. تحليل مصطلحات البحث: استراتيجية الإثارة العشوائية: عرفت استراتيجية الإثارة العشوائية بأنها: "إيجاد تقارب لم يكن موجودًا من قبل في

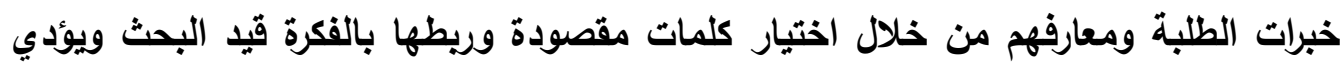

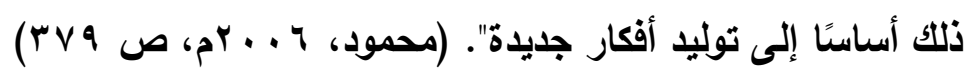
وعرفت بأنها قرة المتعلم على إنشاء علاقات وروابط بين أثشاء لا توجد بينها

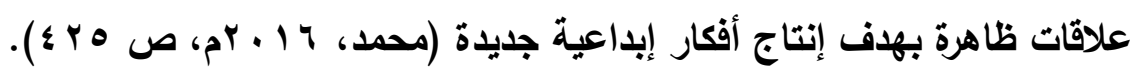

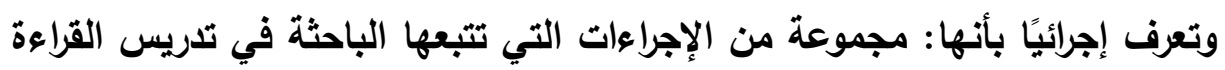
وتثتمل على مجموعة من الخطوات هي: التمهيد - قراعة النص - تحديد وتقديم المفرداتتقديم المثيرات العشوائية- تقديم الأفكار وإيجاد العلاقات - التسجيل - التلخيص. 
الثروة اللغوية:

لكمة الثروة اللغوية مرادفات أخرى منها: المفردات - المحصول اللفظي- المحصول

اللغوي- الحصيلة اللغوية- الذخيرة اللغوية- الرصيد اللغوي. لكن تعدد المرادفات لا يخفي مرادي المراد من الثروة اللغوية، وهو المفردات المكتوية والمنظوقة التي يفهمها الطقل ويكون قادرًا

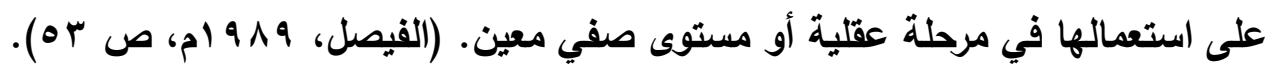
ويقصد بالثروة اللغوية إجرائيًا: حصيلة التلاميذ من المفردات اللغوية الجديدة التي مدين يستطيعون معرفة معانيها ودلالاتها، ومضادها، وجمعها، ومفردها، وتوظيفها في جمل جديدة.

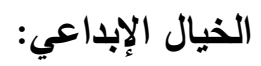

عرف الخيال الإبداعي بأنه "تشاط عقلي مركب وهادف توجهه رغبة قوية في البحث عن حلول أو التوصل إلى نواتج أصلية لم تكن معروفة سابقاً، ويتميز بالشمولية والتعقيد لأنه ينطوي على عناصر معرفية وإنفعالية وأخلاقية متداخلة تشكل حالة ذهنية فريدة". (لبابنة، $\cdot\left(r^{2} \cdot 11\right.$

ويمكن تعريفه إجرائيًا في البحث الحالي: بأن الخيال الإبداعي يتمثل من خلال الانخراط في التفكير حيث يبحث في إيجاد العديد من الاستجابات الممكنة بدلًا من واحدة، والسماح للتلاميذ في التفكير في اقتراحات عاصفة ومجنونة وكذلك تبدوا غير معقولة، وعدم الحكم على الأفكار في وقت مبكر من العملية، ومعالجة الأفكار كما لو أنها قد تحتوي على بذور يحتمل أن تكون مفيدة، مع العلم أنها قد تحتوي على اقتراحات غير قابلة للتطبيق وقد تكون سخيفة. ويقاس بالدرجة الكلية والدرجات الفرعية (الطلاقة، المرونة، الأصالة، الحيوية) التي يحصل عليها التلميذ في مقياس الخيال الإبداعي من إعداد الباحثة.

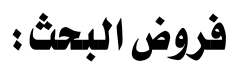

ا- يوجد فرق ذو دلالة إحصائية عند مستوى (1 +. +) بين متوسطي درجات المجموعة التجريبية والمجموعة الضابطة في التطبيق البعدي لاختبار الثروة اللغوية لصالح المجموعة التجريبية. ץ- يوجد فرق ذو دلالة إحصائية عند مستوى (1 (. +) بين متوسطي درجات المجموعة التجريبية والمجموعة الضابطة في التطبيق البعدي لاختبار الخيال الإبداعي في كل مهارة على حدة، والمهارات ككل لصالح المجموعة التجريبية. 


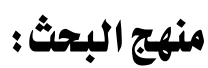

في ضوء أهداف البحث تم استخدام المنهج الوصفي في استقراء الأدبيات السابقة المرتبطة بمتغيرات البحث لإعداد أدوات البحث ومواده، كما تم استخدام المنهج التجريبي؛ حيث تم التطبيق القبلي لأدوات القياس على المجموعتين التجريبية والضابطة، ثم تدريس البرنامج للمجموعة التجريبية، ثم التطبيق البعدي لأدوات القياس على المجموعتين التجريبية والضابطة.

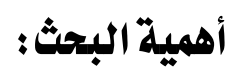

ترجع أهمية البحث إلى أنه قـ يفيد كلًا من:

1- المتعلمين: تنمية الثروة اللغوية والخيال الإبداعي لديهم.

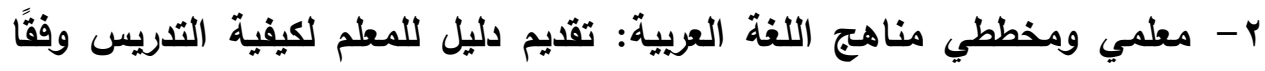
لاستراتيجية الإثارة العشوائية، واختبار للثروة اللغوية واختبار للخيال الإبداعي يمكنه الاسترشاد بهما في عمليتي التدريس والتقويم. r- الباحثين: حيث يفتح المجال أمام الباحثين لإجراء مزيد من البحوث المتعلقئة بتنمية

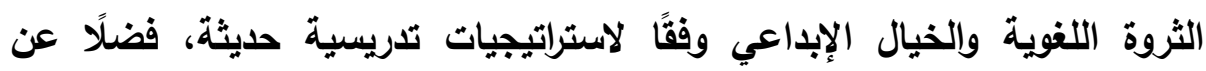
البحث في تأثير استراتيجية الإثارة العشوائية في تنمية مهارات أخرى في مراحل دراسية مختلفة.

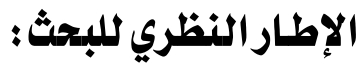
يهاف عرض الإطار النظري للبحث إلى استخلاص إجراءات تنفيذ الدرس باستخدام

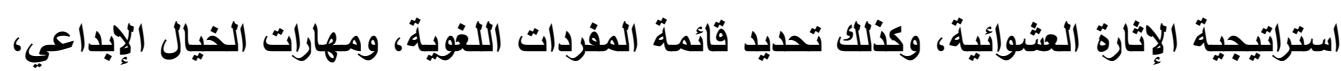
التي يسعى البحث لتنميتها لاى تلاميذ الصف الخامس الابتائي الأزهري؛ ولتحقيق ذلك التهائ يعرض الإطار النظري ثلاثة محاور رئيسة هي: استراتيجية الإثارة العشوائية المفهوم

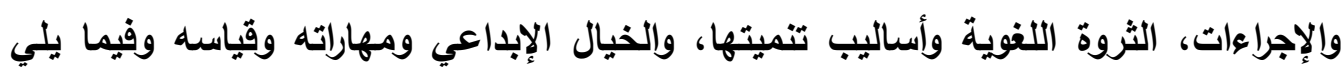
تفصيل ذلك. 


\section{الإثارة العشوائية: المفهوم والإجراءات}

نشأت استراتيجية الإثارة العشوائية وتطورت في أحضان الصناعة الأمريكية ثم تم

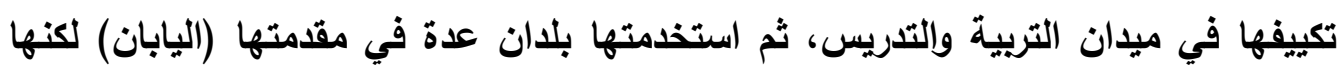
للأسف لا تزال غريبة نسبيًا عن فكرنا النفسي والتربوي فهي تمثل التفكير الإبداعي للطالب فيان فئان عن طريق إيجاد علاقات جديدة بين أثياء لم تكن معروفة من قبل الماتل

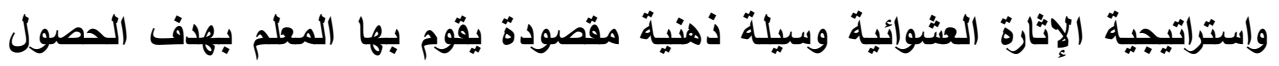
على أكبر عدد من الأفكار من مجموعة معينة خلال زمن معين؛ بغية حل مشكلة بطريقة

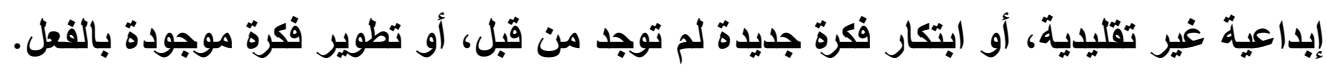

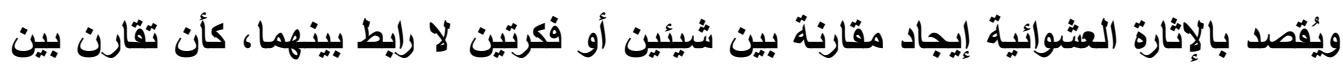

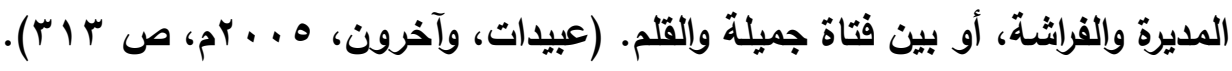

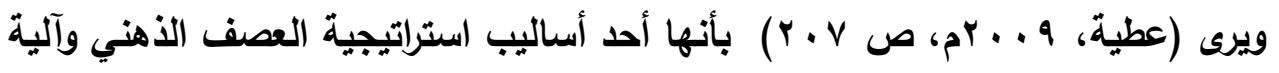
من آليات التفكير الإبداعي نلجأ إليه عندما نكون بحاجة إلى توليد أفكار جديدة، ونختار كلمة

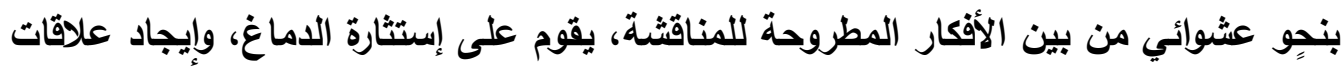

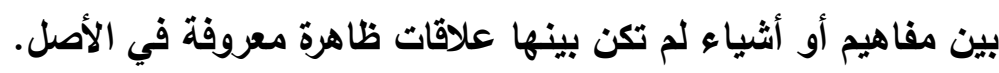

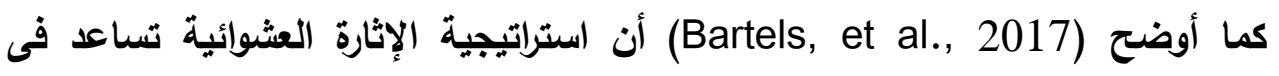
تحويل التعليم الى ممارسات من خلال تحويله الثثك والإثارة إلى ممارسة تقوم على المناقثنة والحوار وتقديم حلول ابتكارية للمشكلات وطرح اسئلة خالقة تحفز على انتاج أفكار جليدة وإقامة علاقات جليدة بين المفاهيم. ويناءً على ذلك فإن الإثارة العشوائية هي استراتيجية لإنتاج أفكار جليدة، ولذانلك يمكن

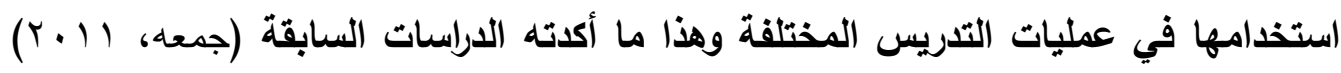

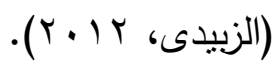

\section{مميزات استراتيجية الإثارة العشوائية:}

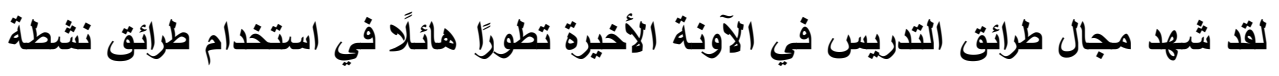

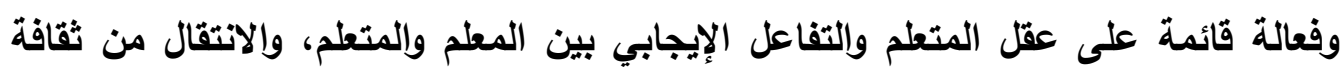

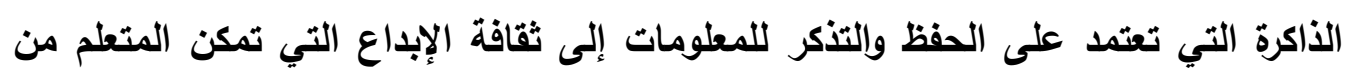


توظيفها في المواقف المخلتفة(Nayak,et al., 2004 p.12) ومن تلك الاستراتيجيات استراتيجية الإثارة العشوائية والتي من مميزاتها أنها: أ- تنمي قدرة الطالب على التفكير الإبداعي. ب-تحقق فهمًا معرفيًا للموضوع. ج- تساعد في تصحيح المفاهيم والمعلومات. د - تزيد من فاعلية التلميذ في عملية التعلم.

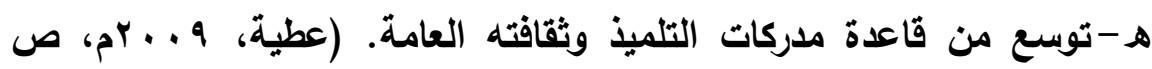

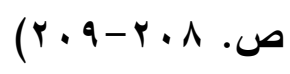

ويالإضافة لما سبق هناك بعض المميزات التي يمكن تحقيقها من خلال إجراءات

تنفيذ استراتيجية الإثارة العشوائية مع التلاميذ منها: تنمي مهارة التأمل في الأمور المطروحة والنظر إليها بشكل مختلف من عدة جوانب. تنمي الوعي بأهمية الوقت أثناء التفكير. تولد الحماسة لعملية التعلم؛ فبواسطة السيطرة على الخيال يتقدم معظم التلاميذ

$$
\text { بسرعة. }
$$

تنمي مهارات الاتصال لاى التلاميذ.

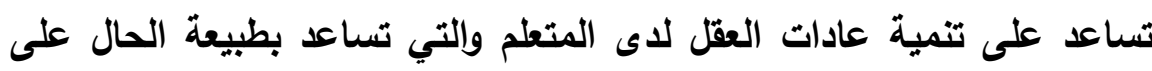
تنظيم المخزون المعرفي للمتعلم وإدارة أفكاره بفاعلية، وتدريبه على تنظيم الموجودات بطريقة جديدة، والنظر إلى الأثياء بطريقة غير مألوفة لتنظيم المعارف الموجودة لحل المشكلات (Deneen, 2010 p. 33).

إجراءات تنفيل الدرس بـاستخدام استراتيجية الإثارة العشوائية : في ضوء ما سبق يمكن تطبيق استراتيجية الإثارة العشوائية في تدريس القراعة وفق

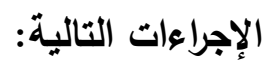
أ- التمهيد: يقوم المعلم بالتمهيد للارس عن طريق تعريف التلاميذ بأهداف الدرس

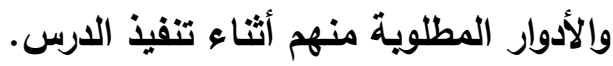


ب-قراءة النص: يقوم المعلم بقراعة النص قراعة صحيحة ومعبرة، ثم يطلب من بعض تلاميذه القراءة بالتتاوب. ج-شرح النص: يقوم المعلم بمناقشة تلاميذه في أفكار النص وشرح المعاني الإجمالية للنص. د - تحديد وتقديم المفردات: يطلب المعلم من تلاميذه إعداد جدول من ثلاث أعمدة

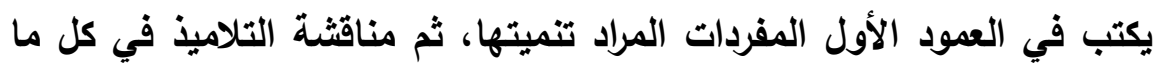
يتعلق بها من شرح المعنى المرادف والمضاد والجمع والمفرد واستعمال المفردة في تعبيرات متباينة. هـ - تقديم المثيرات العشوائية: يطلب المعلم من تلاميذه أن يكتبوا في العمود الثاني من الجدول بعض المثيرات العشوائية، التي قام المعلم بإعدادها مسبقًا، ومناقشة التلاميذ في كل ما يتعلق بالمثيرات من أسئلة من قبل التلاميذ. و - تقديم الأفكار وإيجاد العلاقات: مطالبة التلاميذ بتقديم العلاقات بين المفردات ويين المثيرات المطروحة، وتقبل ما يطرحه التلاميذ من أفكار لكي نحصل على لئ المزيد من الأفكار والعلاقات. ز - التسجيل: يقوم التلميذ بتسجيل الروابط التي تم التوصل إليها في العامود الثالث

$$
\text { المقابل للمفردات والمثيرات العشوائية. }
$$

ح- التلخيص: يقوم المعلم بتقديم تلخيص لكل ما قدم من علاقات مع إلقاء الضوء على العلاقات التي تتميز بالطلاقة والمرونة والأصالة والحيوية.

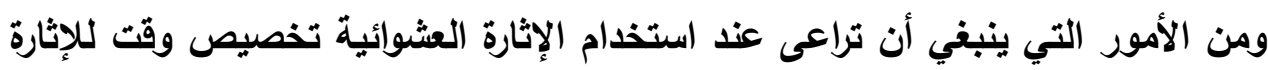

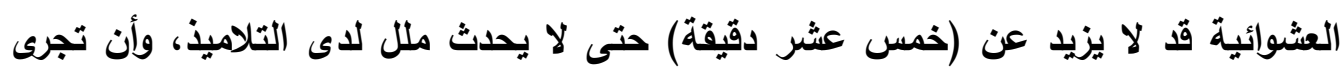

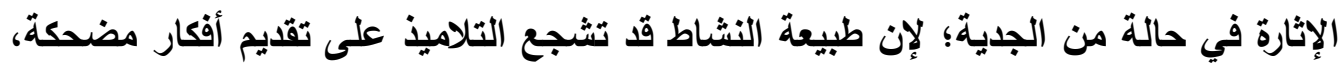
أو أفكار لا علاقة لها بالموضوع، كما يمكن تقديم عدة إثارات عشوائية وليست إثارة واحدة،

ويشجع المعلم التلاميذ على تقديم إثارات عشوائية خاصة بهم. الثروة الافورية وأساليب تنميتها : اختلف الباحثون والمختصون في الإثارة إلى المفردات التي يمتلكها التلاميذ في سن

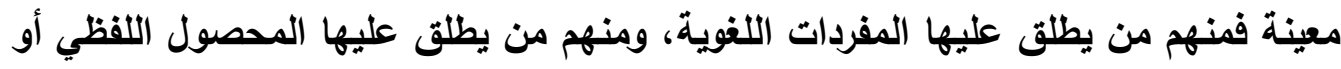


الحصيلة اللغوية، ومنهم من يسميها الثروة اللغوية أو الأخيرة اللغوية؛ لكن لا يُخفي المراد

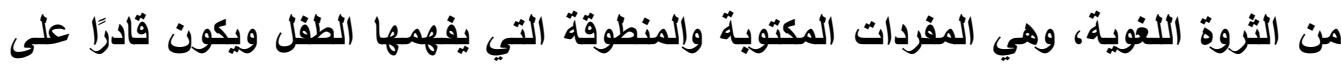
استعمالها في مرحلة عقلية أو مستوى صفي معين. وتعرف الثروة اللغوية بأنها القدرات اللفظية والأسلويية والدلالية الموجودة عند المتكلم والتي تمنحه طاقة تعبيرية خاصة، حيث يتفاوت المتكلمون باللفة الواحدة في مقدار هذه بهاه الحصيلة ونوعيتها والقدرة على استعمالها ، بالإضافة إلى جميع المفردات والتراكيب اللفوية

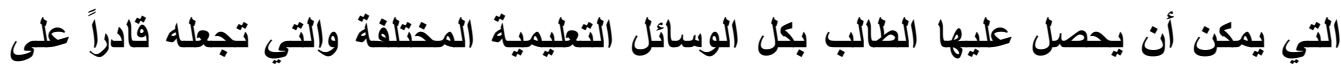

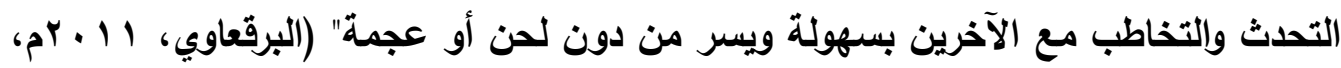
. (rฯ ص يعرفها محمد سعد موسى بأنها حصيلة التلاميذ من المفردات اللغوية التي يستطيع التلاميذ أن يفهموا معانيها بدقة، وتساعدهم على فهم التراكيب اللغوية في الدرس القرائي ويمكنهم استخدامها في جميع أغراض الكتابة التي يمارسونها، ويقاس ذلك من خلال اختبار

$$
\begin{aligned}
& \text { الثروة اللغوية (موسى، ؛ . . بم، ص } 9 \text { (1). } \\
& \text { التعريف الإجرائي للبحث: }
\end{aligned}
$$

ويقصد بالثروة اللغوية إجرائيًا: حصيلة التلاميذ من المفردات اللغوية الجديدة التي يستطيعون معرفة معانيها ودلالاتها، ومضادها، وجمعها، ومفردها، وتوظيفها في جمل جديدة.

أهمية تثمية الثروة اللفوية :

تتبين أهمية الثروة اللغوية في الدور الأساسي الذي تلعبه أو تؤيده في عملية التواصل والتعايش والترابط والتفاعل الاجتماعي، وفي اكتساب الخبرات وفي تنشيط عملية الإبداع والإنتاج الفكري.

كما أن اللغة منهج أي مادة أو محتوى؛ وهذا يعني أن التحصيل الاراسي للطفل يعتمد على الاستعمال الفعال للغة. ولا شك في أن نجاح الطقل مرتبط بقدرته على القراءة بفهم،

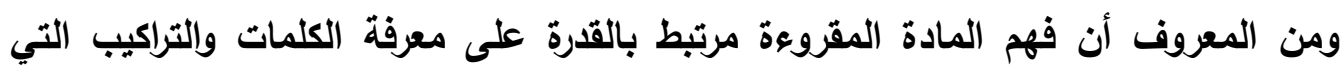
تضمها هذه المادة. فإذا وفرت للطقل ذخيرة من المفردات، ودُرب على الأنماط اللغوية ساعدناه على فهم ما يقرؤه وجعلنا تفكيره سليمًا في أي مشكلة أو مادة دراسية. (الفيصل،

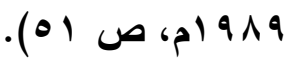


وفي المقابل فإن التلاميذ الذين يملكون مفردات لغوية قليلة يُبدون تفكيرًا ضعيفًا لأية

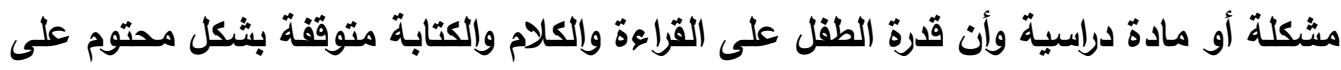

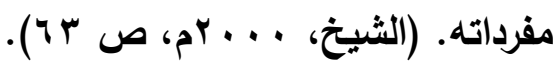

في ضوء ذلك يمكن توضيح أهمية تنمية الثروة اللغوية من خلال إبراز أهم وأخطر

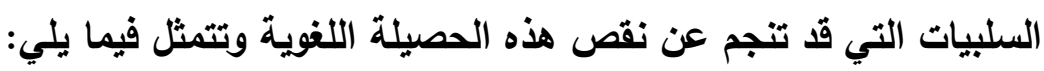

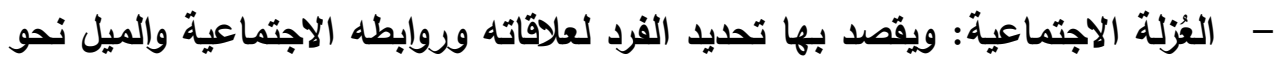
الانفراد والانظواء، فقلة المحصول اللغوي تؤدي لضعف عباراته وأساليبه وقلة قدرته على التواصل والتخاطب والتفاهم مع الآخرين. - اضطراب الثخصية: إن عجز الإنسان عن التعبير عن مشاعره وأفكاره بصورة طليقة وعجزه عن التواصل الاجتماعي بمرونة كافية قد يولا على مرور الزمن شعورًا

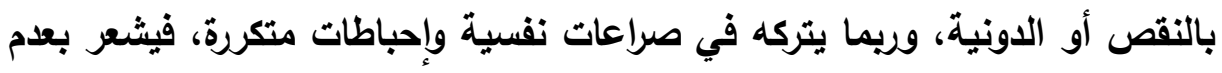

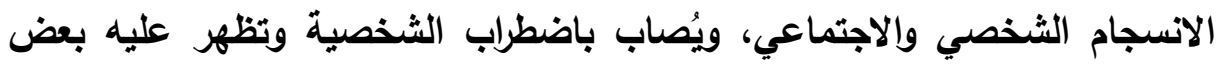

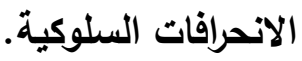
- - ضيق الأفق الثقافي والفكري: فالمفردات اللغوية هي بوابة الإنسان الرئيسية التي يصل من خلالها إلى عقول وأذهان وأحاسيس أبناء جنسه، ويشكل بما يكتسبه منها

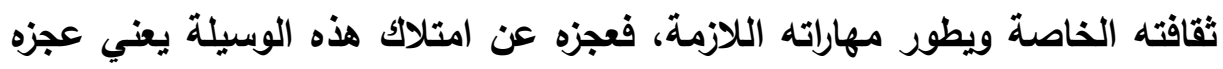
عن اكتساب المعارف والخبرات وتعثره في فهمها، وعن التطوير لما يحتاج إليه من فنانه

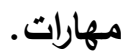
-

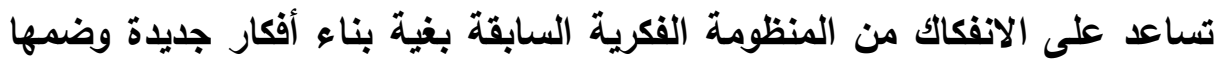
ومشاعرها المرافقة في ارتباطات وعلاقات مبتكرة" ويتم نقله بصورة أساسية بواسطة

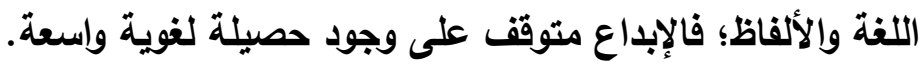
- هجران اللغة أو اتهامها بالعجز: كثير ممن ضعفت حصيلته من مفردات اللغة وصعب عليهم التعبير بلغتهم بطلاقة، تميل بهم العاطفة أو يدفعهم الجهل أحيانا فلا يقرون بعز قدراتهم وتقصيرهم تجاه اللغة، وإنما ينسبون العجز والضعف إلى اللغة 
نفسها فيتهونها بالضيق والفقر، وينسبون مفرداتها إلى الثقل والغرابة والقصور عن

$$
\text { مجاراة تطورات الحياة. }
$$

- - الازدواجية اللغوية: إن الإحساس بالضعف في اللغة والعجز عن استخدامها بمرونة

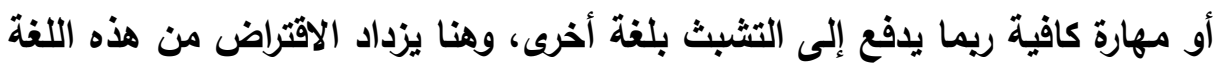
الأجنبية، ويكثر التاخل بينها ويين اللغة الأصلية فينشأ ما يُسمى بالازدواجية

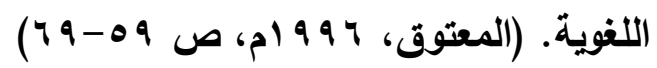
مما سبق يتضح أهمية ثراء الحصيلة اللغوية وضرورة تنميتها لاى التلاميذ؛ حيث أن الثراء اللغوي اللفظي يعين التلميذ على إدراك واستيعاب ما يقرأ وذلك يدفعه إلى الاستمرار في القراءة، مما يكسبه ثقافة وعلمًا. كما يعينه على فهم واستيعاب إنى قواعد اللغة وأصول نحوها وصرفها؛ ويالتالي تعينه على توظيفها في التعبير عن أفكاره وأحاسيسه.

\section{أساليب ثنمية الثروة اللفوية :}

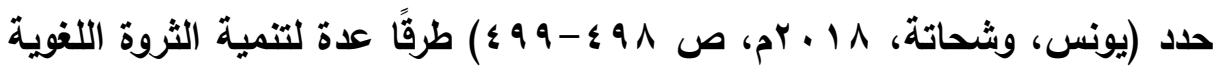

> الخبرة المباشرة: ويمكن أن تقدم الخبرة المباشرة في صور عديدة داخل المدرسة

وداخل الفصل واستدعاء هذه الخبرة بالتدريبات والأنشطة المختلفة. > القراءة الواسعة: وتعتبر خبرة غير مباشرة، وهي وسيلة مناسبة لتنمية مفردات

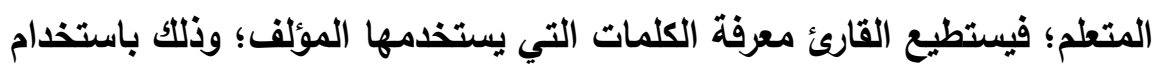
المُعجم للتعرف على معناها واشتقاقاتها المختلفة. > دراسة الكلمة: وذلك باستخدام الوسائل التي يمكن بها أن نعرف معاني الكلمات التهات

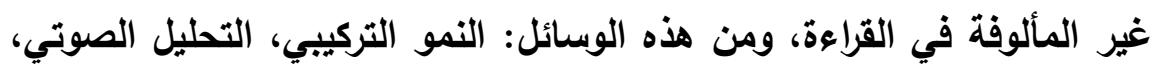
استخدام السياق، استخدام المعاجم. > استخدام الكلمات الجديدة في الأنشطة اللغوية المختلفة: فمن الضروري استخدام المفردات الجديدة في كل الأنشطة اللغوية المختلفة لكي تضمن حفظها ويقاءها لاى المتعلم ومن هذه الأنشطة: التقريرات المكتوية، المناقشات، المحادثات الشفويةة. .إلخ. 
> التدريب على استخدام الكلمات: ويساعد ذلك في تنمية المفردات، وفي استخراج كلمات كثيرة من أصول قليلة، مما يترتب عليه تغير في المعنى، ويالتالي تزويد الثروة اللغوية.

وأشار الباحثون إلى العديد من الأساليب التي يمكن استخدامها لتنمية الثروة اللتغوية

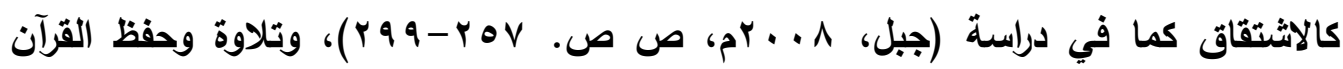

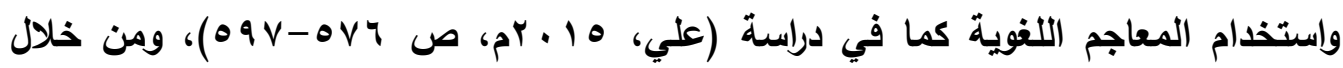

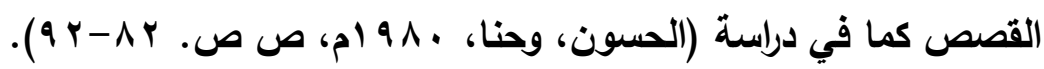
ويرى (خاطر، ورسلان، . ... بم، ص 1 1. 1) أن زيادة المفردات اللغوية من الأمور

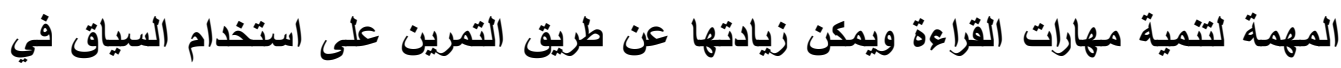

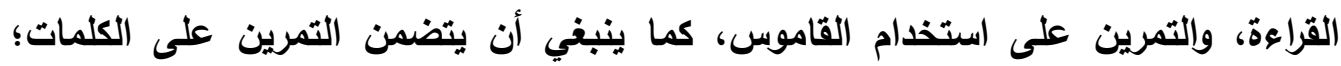
التحليل الصرفي، وتصنيف الكلمات على أساس معين كالمترادفات والمتقابلات، وعمل قوائم كلمات كالأوصاف مثلًا. مما سبق يتضح أن لطريقة تقديم المفردات اللغوية للتلميذ أثرًا كبيرًا في استيعابهم لها وإقبالهم عليها، فتقديمها في صورة تمارين نمطية وطريقة تقليدية لا تساعد على تطور لغة التلميذ وإنما تبلا ذهنه وتحد من طلاقته اللفظية ومن قدرته على الإبداع الفكري واللغوي،

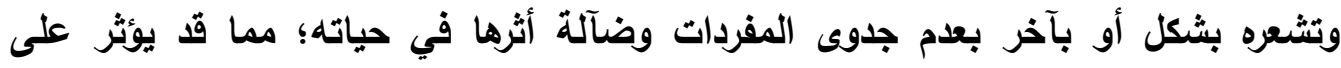
اهتمامه بتحصيلها. ولذلك ينبغي تقديم المفردات بطريقة نشطة وفعالة قائمة على عقل المتعلم، والتفاعل الإيجابي بين المعلم والمتعلم، والانتقال من الطريقة القائمة على التذكر والحفظ إلى ثقافة الإبداع التي تمكن المتعلم من توظيفها في المواقف المختلفة، وهو ما يمكن أن تقوم به استراتيجية الإثارة العشوائية؛ حيث أنها استراتيجية تؤكد تنمية المهارات الإبداعية بشكل

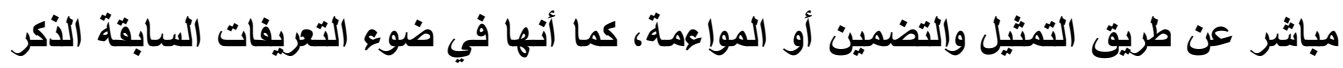
نجد أنها استراتيجية تستخدم لمساعدة المتعلمين في توليد أفكار جديدة أو بديلة، وتسعى فوعليق لتطوير الأفكار وتحسينها، والخروج منها إلى فكرة إبداعية من خلال مجموعة من الإجراءات. 
> معايير امتلاك التلاميذ للثروة اللغوية: هناك عدد من المعايير التي يمكن الحكم من خلالها على امتلاك التلميذ لمادة لغوية واحتسابها من ثروته اللغوية وهي:

1- فهم المغنى: فلا تعد الكلمة من ثروة التلميذ اللغوية ما لم يكن مدركًا معناها. r- ضبط بنية اللفظ: فقد يدرك التلميذ اللفظ ولكن ينطقه خطأ، وهذا النطق الخطأ يعوق الفهم أو يؤدي إلى فهم خاطئ. ץ- صحة كتابة الكلمات: إذ تعبر الكتابة عن صحة فئه مخارج الألفاظ وكثيرًا ما يعوق خطأ الرسم فهم المغنى ويعيب صاحبه.

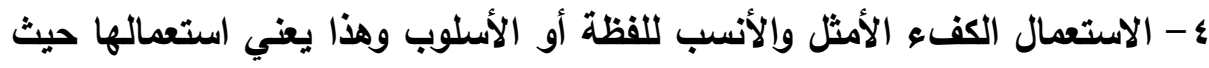

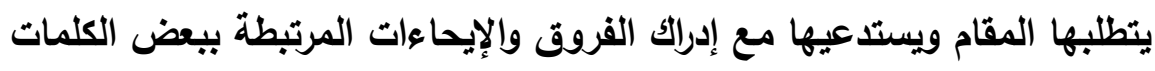

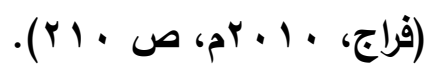

في ضوء ذلك سعت الباحثة أن يقيس اختبار الثروة اللغوية خمسة أجزاء يمكن من خلالها

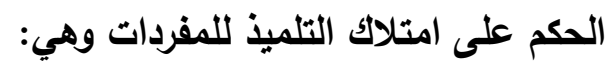
- - الجزء الأول: مرتبط بالمعنى أو المرادف، وهذا الجزء يقيس مدى قلئرة كل تلميذ على استداءع الكلمة المرادفة للكلمة المحددة.

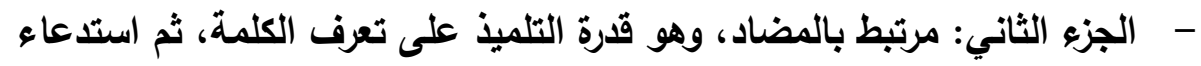
الكلمة المضادة لها.

- - الجزء الثالث: مرتبط بالمفرد، وهو قدرة التلميذ على تحديد مفرد الكلمة.

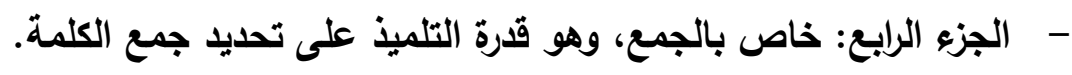
- الجزء الخامس: خاص باستعمال المفردة، وهو قدرة التلميذ على استعمال المفردة في تعبير جديد. الخيال الإبلداعي مهاراته وقياسه : نستعرض في هذا الجزء من البحث تعريف الخيال الإبداعي، وأهيته، ومهاراته، وطرق تنميته وقياسه، والعلاقة المتبادلة بينه ويين ثراء اللغة، وهذا ما سنتناوله بالتفصيل فيما يلي. تعريف الخيال الإبداعي: 
الخيال الإبداعي بنائي ويتضمن الكثير من عمليات الامج والتركيب وإعادة تركيب وترتيب الأكرة الخاصة بالخبرات الماضية، وكذلك الصور التي يتم تثكيلها وتكوينها خلال ذلك في تركيبات جديدة.

ويشكل الخيال الإبداعي أحد أشكال التفكير، وفيه يعالج الفرد أي ظاهرة نفسية وعقلية أو مواقف وخبرات ومشكلات بطريقة إبداعية؛ فالخيال الإبداعي هو العملية التي يتم فيها بهابها الإحساس بالمشكلة والكثف عن الثغرات فيها، والبحث عن الحلول والمقترحات بهدف الوصول إلى حل تلك المشكلة (Tsai, 2012). ويعرفه فؤاد البهي بأنه "العملية العقلية التي تقوم على إنشاء علاقات جليدة بين الخبرات السابقة، بحيث تنظمها في صور وأثنكال لا خبرة للفرد بها من قبل وهي تستعين بقرات التذكر والاسترجاع والصور العقلية المختلفة في إنشاء هذه التنظيمات الجديدة"

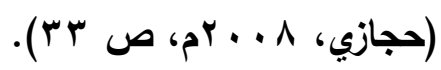
ويعرفه حسن إبراهيم بأنه "القدرة العقلية النشطة على تكوين الصور والتصورات الجديدة"

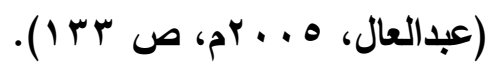
وينقسم الإبداع الخيالي إلى ثلاثة أقسام:

الخيال الإبداعي المطلق: وهو لا يخضع للإدارة وليس لله غرض مقصود معين، ولا يتقيد بالماضي ولا بالمستقبل، وهذا النوع يكون في صورة أحلام اليقظة. الخيال الإبداعي المقيد: وهو ذو غرض مقصود ياركه ويشعر به الإنسان ويعمل

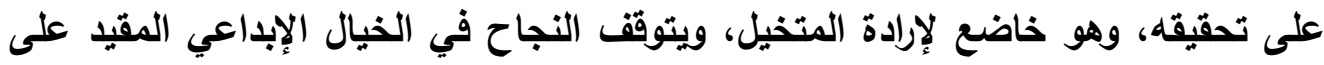
مقدرة المتخيل العقلية، ومقار ما لديه من معلومات أو معرفة، ومدى تجاريه الخاصة.

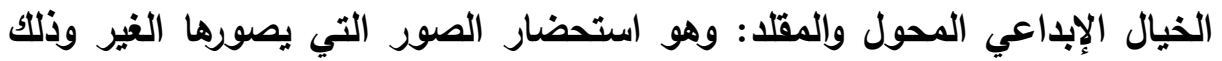
كما يفعل الطالب حين يصغي لأستاذه وهو يصف له مدينة أو منظرًا رآه، فهو محول لأن المتخيل يحول الألفاظ والعبارات إلى صور، ومقلد لأن المتخيل يقلد غيره في استحضار

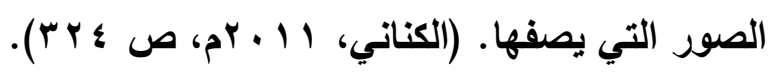
ويعرف إجرائيًا في البحث الحالي: الارجة الكلية والدرجات الفرعية (الطلاقة، المرونة، الأصالة، الحيوية) التي يحصل عليها التلميد في مقياس الخيال الإبداعي من إعداد الباحثة.

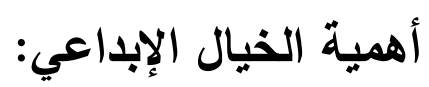


يعد الخيال نشاطًا عقليًا يقوم به الإنسان يتفكر به بكل ما حوله وينقله إلى أماكن بعيدة

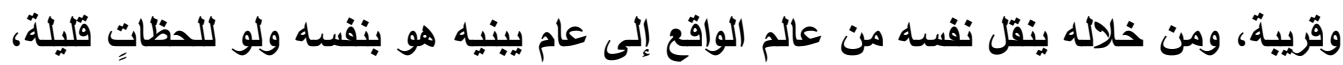
وقت أثرَّ الخيال في تظور حياة الإنسان حيث جعله يصل إلى أساليب وابتكارات سهلت من بن

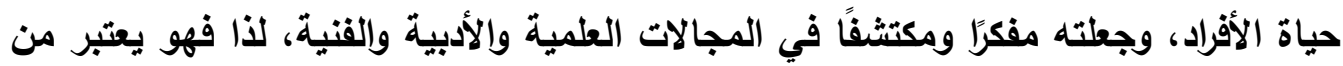
أهم الوسائل التي أدت إلى تطور البشرية، ويمكن إجمال أهمية تنمية الخيال الإبداعي لدى الطقل فيما يلي:

1- - تنمية القدرة على التصور لما ستكون عليه الأثياء والأحداث في المستقبل وكيفية الاستعداد لمواجهتها، ويالتالي يمكن القول بأن تنمية الخيال مدخل ضروري للكشف عن المبدعين والمتميزين.

r - ت تمية قدرات التفكير الناقد لدى الطفل فهو يساعده على تقييم المعلومات وفحص الآراء مع الأخذ بعين الاعتبار وجهات النظر المختلفة حول الموضوع قيد البحث. فالتفكير الناقد يتضمن العديد من القدرات أهمها الطلاقة في التفكير، والقدرة على النقد البناء، وتقييم المعلومات، والبحث عن بدائل، وكذلك القدرة على الاستتتاج، والتمييز بين الحقائق وغير الحقائق.

r- - تنمية مهارة حل المشكلات فهذه المهارة تستخدم لتحليل ووضع استراتيجيات تهذف إلى حل سؤال صعب، أو موقف معقد، أو مشكلة تعيق التقدم في جانب من جوانب الحياة. فعندما يواجه الطقل مشكلة فإنه يحاول حلها والتظلب عليها في ضوء الإمكانات المتاحة لايه، وذلك من خلال خطوات حل المشكلة. ع - - ت تمية الثقافة العلمية لاى الطقل فيكون الطقل بذلك قادرًا على اكتساب الحقائق والمفاهيم العلمية، وتطبيقها على مواقف حياته اليومية، بالإضافة إلى فهم الأفكار العامة لخصائص العلم والإلمام باتجاهات وميول القيم المتعلقة بالعلم. وعليه فإن الثقافة العلمية للطفل تعني ربط ما يتعلمه هذا الطقل من حقائق ومفاهيم علمية من خلال أسرته ومدرسته ووسائل الإعلام المختلفة. - - - تشجيع الأطفال على القراءة والإطلاع وإشباع حب الاستطلاع لايهم؛ حيث تعد القراءة عملية مهمة في تكوين الرأي وتقدير المواقف ونقد الأفكار، فعندما يمارس الأطفال أنشطة القراءة فهم يتصورون ويتخيلون ما يقرأون من أحداث وما يواجهه بطل أو أبطال 
الرواية من مشكلات، فيندفع الطقل من تلقاء نفسه نحو الاستطلاع وهذا التوجه بحاجة

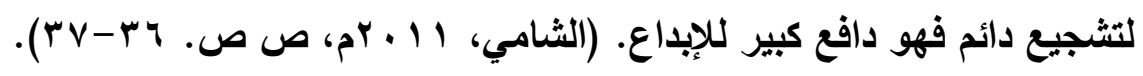

ونظرًا لتتلك الأهمية أوصت العديد من الدراسات بضرورة الاهتمام بتتمية مهارات الخيال

الإبداعي في المراحل التعليمية المختلفة وخصوصا المراحل التعليمية الأولى ومنها: دراسة الاسة

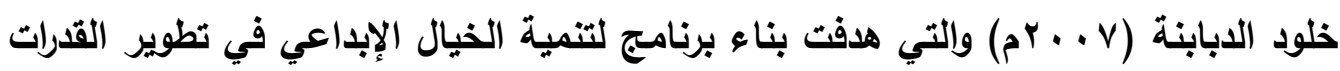
الإبداعية عند الأطفال من عمر (^-^) سنوات تلاميذ الصف الثاني الأساسي (الدبابنة،

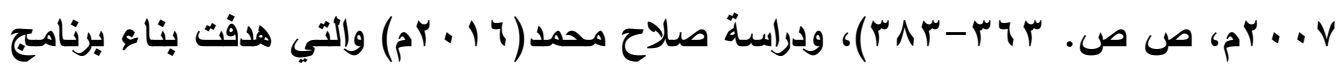
قائم على أنشطة نادي الفضاء في تنمية مهارات الخيال (الوعي، التصور، أحلام اليقظة، الانسحاب من الواقع، المرونة، الاحتفاظ بالاتجاه) لدى تلاميذ الصف السادس الإبتدائي

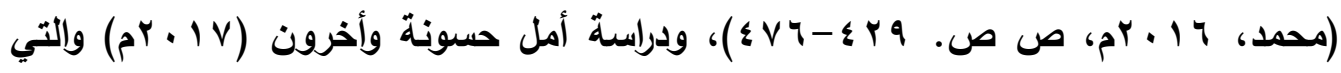
هدفت إلى بناء برنامج تدريبي قائم على الخرائط المعرفية لتنمية الخيال الإبداعي لدى أطفال

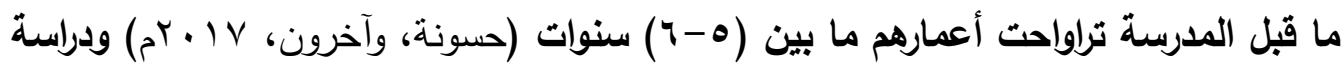
أحمد إبراهيم والتي هدفت التعرف على أثر استراتيجية الألعاب اللغوية في تنمية مهارات

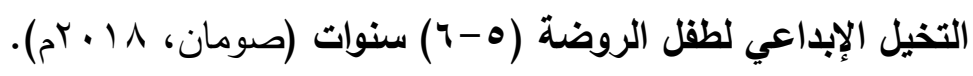

\section{العلاقة بيز الإبلداعوالخيال :}

يعد الخيال قاسمًا مشتركًا في جميع الأنشطة الإبداعية ولذلك ربط العديد من الباحثين

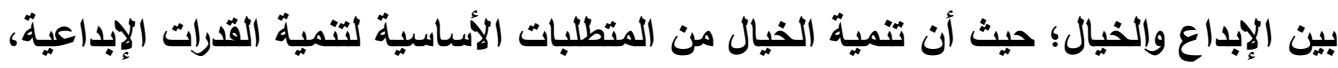
فالإبداع هو حصيلة لتفاعل المعرفة التي يمتلكها الطفل، والقدرة على التخيل، وريط الخبرات السابقة المخزونة في الذاكرة وتركيبها، ووضعها في تركيبات جديدة، وتكوين تصورات ذهنية

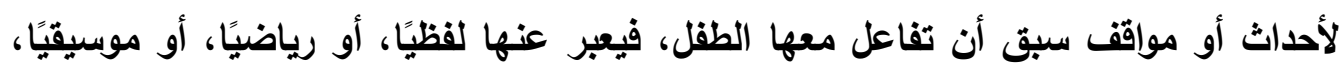

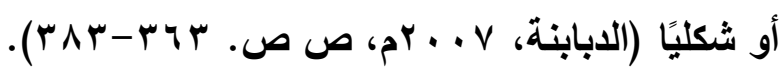

ويرى كثير من العلماء أن الخيال مهارة عقلية ترتبط ارتباطًا وثيقًا بالإبداع؛ حيث

يتفاعلان مع بعضهما البعض، فالتخيل عملية عقلية تحدث في عقل الطقل لتصور ما يمكن أن تكون عليه الأثياء اسستنادًا إلى خبراته السابقة بفهم الماضي، وتحسين المستقبل، أما الإبداع فهو طريقة من طرائق التفكير القائمة على دمج المعرفة والخبرات السابقة بشكل جديد إيداء لم يكن معروفًا لاى الطقل من قبل؛ إذ يؤدي الخيال دورًا رئيسًا في الطريقة التي يتم بها، 
ومن خلالها دمج المعرفة والخبرات السابقة في حل المشكلات، واقتتراح الحلول المناسبة للمواقف التي تطرأ من حين لآخر. (132- Decety, 2004 pp. 120). ويناءً على ذلك فإن الإبداع يستلزم استخدام خيال القرد في أي موقف معطى له، فلا إبداع بغير خيال، وكلما كان الخيال ممتلئاً وعميقاً كان دليلاً على قدرة إبداعية وتصورية الإناية كبيرة.

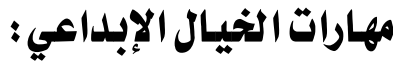

هي عدد من المهارات المنبثقة من مهارات التفكير الإبداعي: الأصالة، والطلاقة، والمرونة، والتوسع، والمؤثرات السلوكية الدالة على كل مهارة من هذه المهارات، والمدرجة الثهات لقياس امتلاك التلاميذ لهذه المهارات الرئيسية للتفكير الإبداعي، من خلال اختبار التهار الخيال الإبداعي المعد لهذا الغرض. ويعد اطلاع الباحثة على العديد من الدراسات والأدبيات السابقة التي تناولت مهارات

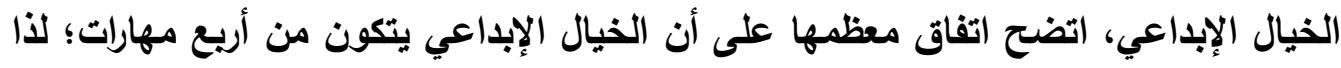

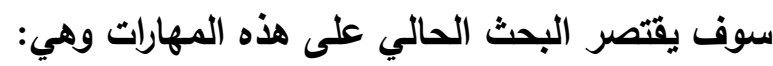
الطلاقة: القدرة على استدعاء أو تكوين أكبر عدد ممكن من الاستجابات، وتعرف إجرائيًا بعدد استجابات التي يمكن أن يأتي بها التلميذ، أي تتضمن الجاتب الكئ الكي.

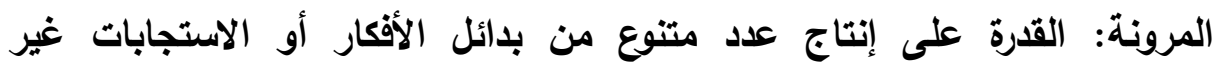

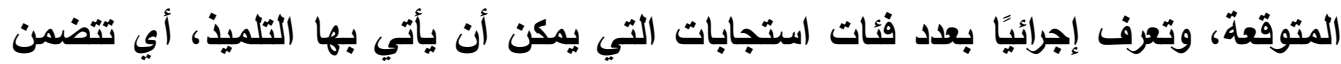

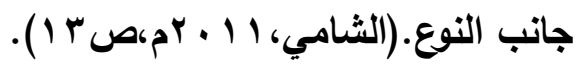

الأصالة: القدرة على بناء استجابات أصيلة، قليلة التكرار بالمعنى الإحصائي داخل

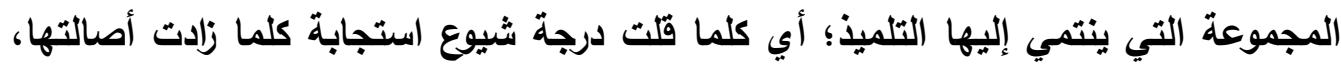

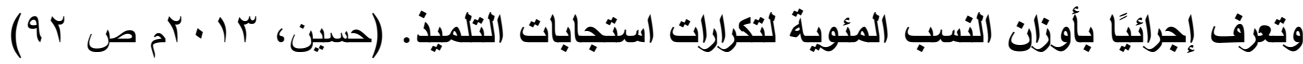
الحيوية: القدرة على إنتاج استجابات تثثير إلى أثياء حية أو متحركة أو داخلة في

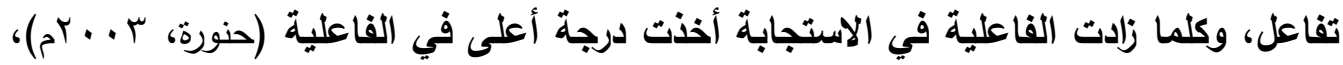

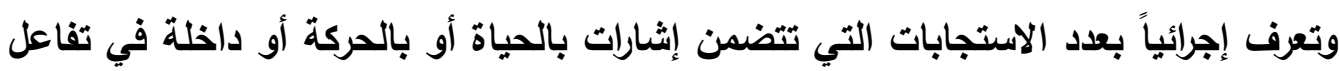
والمناسبة لمثيرات اختبار الخيال الإبداعي المستخدم في البحث الحالي. 
يلاحظ مما سبق أن مهارات الخيال الإبداعي من أهم المهارات التي ينبغي تواجدها لدى تلاميذ المراحل الأساسية وقد استفادت الباحثة من ذلتك عند إعداد اختبار الخيال الإبداعي.

$$
\text { طرق تتمية الخيال الإبداعي وقياسه: }
$$

هناك العديا من المداخل التي تنهض بتنمية الخيال الإبداعي يمكن إجمالها فيما

أ- - مدخل الأساليب العملية (الإجرائية): وتتضمن تدريبات من قبيل العصف الذهني

والتآلف بين الأثتات والتي تعتمد على التشبيه والاستعارة والريط بين المتباعدات. لالتهن

ومن الأساليب المناسبة أسلوب الحل المبدع للمشكلات وهو أسلوب يعتمد على لئل المُضي في خطوات تبأ بالإحساس بالمشكلة والحاجة إلى حلها، ثم تحديد المشكلة وجمع الحقائق والتفكير في مختلف الحلول وإختيار الحل المناسب وإختبار كفاءة الحل المختار.

ب- مدخل الأساليب التريوية: ويتضمن استخدام طرق من قبيل التفكير المنتج ويرنامج التدريب على الحل الإبداعي للمشكلات ويرنامج التدريب على حل مشكلات المستقبل.

ج- مدخل الأساليب العلاجية: ويهتم هذا المدخل بالتركيز على الطرق المستخدمة في العلاج النفسي والتدريب على استثمار العائد الحيوي للتحكم في الانفعالات

$$
\begin{aligned}
& \text { والوظائف الفسيولوجية. (حنورة، } 999 \text { (ام، ص ء צ). } \\
& \text { قياس الخيال الإبداعي: }
\end{aligned}
$$

يستخدم معظم الباحثين الذين يقومون بلراسة ظاهرة الإبداع عددًا من الاختبارات العقلية التي تقيس القدرة على الإنتاج الإبداعي ويوجد العديد من الاختبارات التي تقيس بعض عوامل التفكير الإبداعي: كالأصالة والمرونة والطلاقة ومن أهم هذه الاختبارات: اختبار البدائل الممكنة، اختبار الرسومات الناقصة، اختبار استعمالات الأشياء، اختبار النتائج

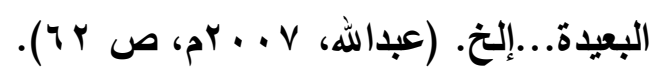

وفي ضوء ذلك حاولت الباحثة تحديد الهرف من المقياس، وتحديد المكون الذي يتم قياسه؛ من خلال إعداد اختبار مهارات الخيال الإبداعي (الطلاقة، المرونة الأصالة، الحيوية). 


\section{العلاقة بين ثراء اللفة والخيال الإبلاعي:}

تؤثر القدرة اللغوية في تكوين الثخصية المبدعة للعلاقة الوطيدة بين اللغة وإلفكر، فمن المطوم أنه لا وجود لذخيرة وافية من الإبداع والعمل الفكري لاى أمة في غياب اللغة، فاللغة

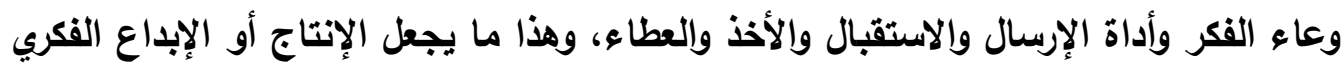

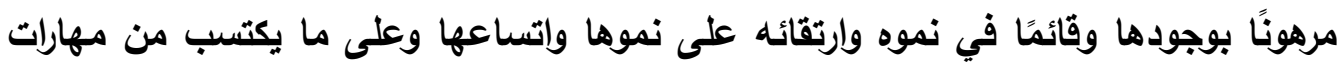

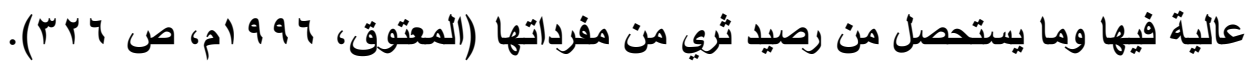

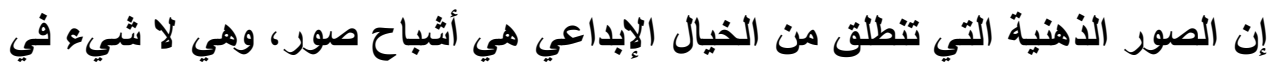

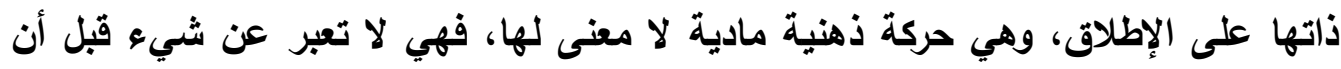

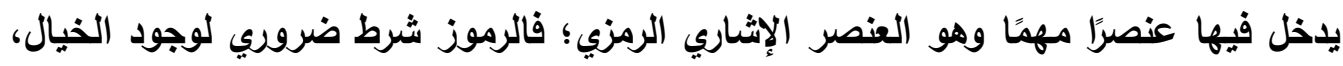

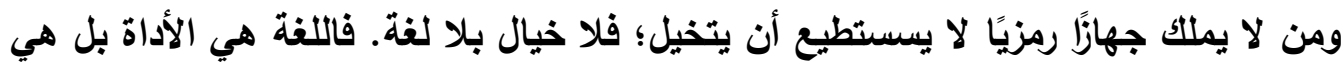

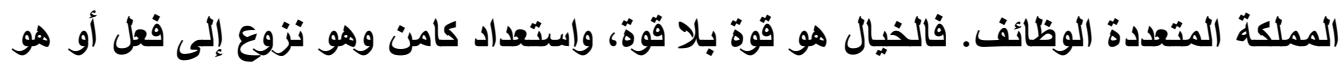

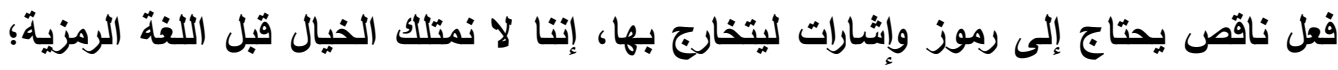

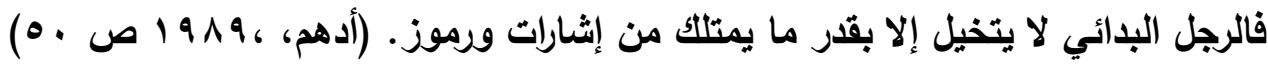
إن اللغة عنصر مهم وحيوي في إثراء الخيال وترى الباحثة أن الثروة اللغوية وتنمية الخيال الإبداعي ضروريان لتعلم اللغة العربية حيث يؤثر كل منهما في الآخر ويتأثر به، الثيأ فالتلميذ الذي يمتلك ثروة لغوية وتتوافر لديه ذخيرة من المفردات قادرًا على فهم ما يقرأ، مما يزيد من قدرته على التخيل السليم؛ فقد تبين أن ثراء اللغة جزء أساسي للخيال الإبداعي من فن فئن خلال التعبير عن الصور الخيالية بالكلمات المناسبة للمعاني والأفكار. رابعاً: إجراءات البحثث: 1- إعداد قائمة المفردات المتضمنة بموضوعات القراءة لتلاميذ الصف الخامس الابتدائي

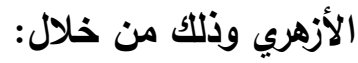

تحليل كتاب اللغة العربية الفصل الدراسي الأول المقرر على تلاميذ الصف

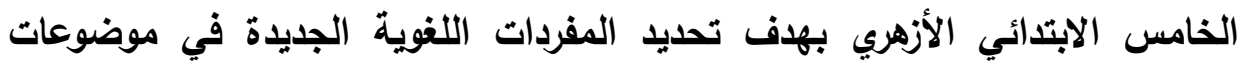

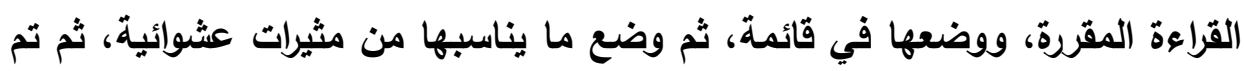
عرض القائمة على مجموعة من الخبراء والمختصين في اللغة العربية وطرائق تدريسها 
لاختيار ثلاث مثيرات عشوائية لكل مفردة؛ وذلك بهاف تنميتها لاى التلاميذ وتم

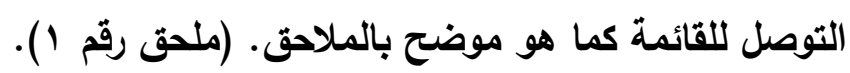

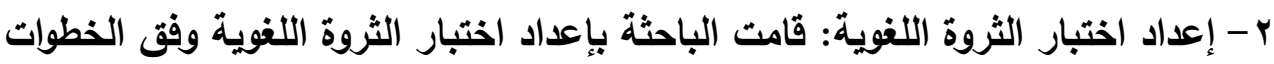
التالية:

أ- - الهدف من الاختبار: يهدف هذا الاختبار إلى قياس مستوى تنمية الثروة اللغوية لاى تلاميذ الصف الخامس الابتدائي الأزهري، وذلك لتعرف مدى توافر المفردات الجديدة لديهم، وكذا أثر استراتيجية الإثارة العثوائية في تنمية الثروة اللغوية من خلال حساب الفروق بين التطبيقين القبلي والبعدي للاختبار . بيتكون الاختبار من تسعة أسئلة؛ موزعة على موضوعات القراءة الثلاثة، كما هو موضح

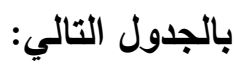

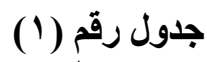

توزيع مفردات الاختبار على موضو عات التوعات القراعة

\begin{tabular}{|c|c|c|}
\hline النسبة & عدد الأسئلة & الموضوعات \\
\hline rr.rr & $\mu$ & حب الوطن \\
\hline rr.rr & $r$ & الكهرباء في حياتنا \\
\hline rr.rr & $\mu$ & تربية الدواجن \\
\hline$\% 1 \ldots$ & 9 & المجموع \\
\hline
\end{tabular}

يتضح من الجدول أن عدد أسئلة الاختبار بلغت تسعة أسئلة، ويبدأ كل سؤال بفقرة من موضوع القراءة، ثم يندرج تحتها خمس أسئلة فرعية يمكن من خلالها الحكم على امتلاك بلك التلميذ للمفردات وهي: المرادف للمفردات، ويعني مدى قدرة كل تلميذ على استدعاء الكلمة

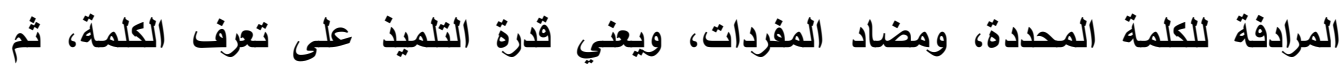

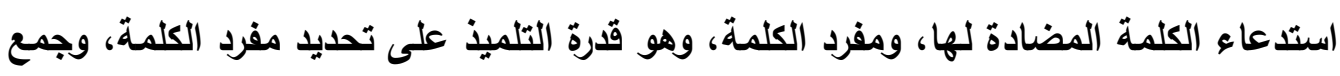
الكلمة، وهو قدرة التلميذ على تحديد جمع الكلمة، بالإضافة إلى استعمال المفردة، وهو قدرة التلميذ على استعمال المفردة في تعبير جديد. والجدول التالي يوضح توزيع المفردات على تلك المعايير: 


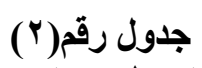

توزيع مفردات الاختبار على معايير امتلاك الثروة اللفوية

\begin{tabular}{|c|c|c|c|c|c|c|c|c|c|c|c|}
\hline \multirow[t]{2}{*}{ النسبة } & \multirow[t]{2}{*}{ المجموع } & \multicolumn{9}{|c|}{ توزيع مفردات الاختبار } & \\
\hline & & 9 & $\Lambda$ & $V$ & 7 & 0 & $\varepsilon$ & $r$ & $r$ & 1 & \\
\hline$\%$ r. & 9 & (أ) & (ج) & (ب) & (ج) & (د) & (أ) & (ب) & (ج) & (ب) & المعنى \\
\hline$\%$ r. & 9 & (ب) & (أ) & (د) & (أ) & (ب) & (د) & (أ) & (ب) & (أ) & المضاد \\
\hline$\%$ r. & 9 & (د) & (ب) & (ج) & (ب) & (ج) & (ب) & (ج) & (د) & (ج) & المفرد \\
\hline$\%$ \%. & 9 & (ج) & (\lrcorner$)$ & (أ) & (د) & (أ) & (ج) & $(د)$ & (أ) & $(د)$ & الجمع \\
\hline$\%$ r. & 9 & (ه) & (ه) & (ه) & () & (ه) & (ه) & (ه) & (ه) & (ه) & المنتعمدال \\
\hline $\begin{array}{l}1 \cdots \\
\%\end{array}$ & $\leqslant 0$ & 0 & 0 & 0 & 0 & 0 & 0 & 0 & 0 & 0 & المجموع \\
\hline
\end{tabular}

يتضح من الجدول أن عدد أسئلة الاختبار بلغت تسع أسئلة، يندرج تحتها خمس وأريعون

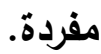

\section{ج- عاب صدق الاختبار:}

حيث قامت الباحثة بعرض الصورة المبائية من الاختبار على مجموعة من المحكمين المختصين وذلك للاستفادة من آرائهم وتوجيهاتهم في تعديل الاختبار. ويذلك أصبح الاختبار

$$
\text { دـ صورته النهائية ( ملحق رقم r). }
$$

قامت الباحثّة بحساب ثبات الاختبار باستخدام إعادة تطبيق الاختبار على العينة

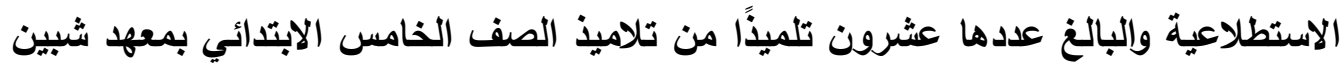
القتاطر الابتدائي الأزهري. بفاصل زمني خمسة عشرة يومًا، ثم حساب الارتباط بين التطبيقين حيث بلغ (Y9. • ) وهي نسبة تعد جيدة في حساب معاملات الثبات، ويمكن الوثوق بها واستخدام الاختبار بناءً عليها في التطبيق على عينة البحث. 
لحساب زمن الاختبار اتبعت الباحثة الخطوات التالية:

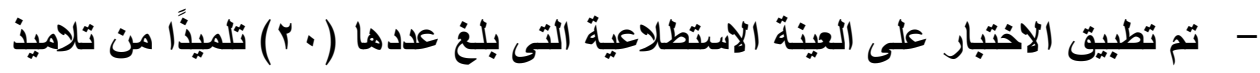
الصف الخامس الابتدائي بمعهد شبين القتاطر الابتدائي الأزهري. - تم حساب زمن كل تلميذ في الإجابة على الاختبار. - تم ترتيب زمن الإجابة عن الاختبار ترتيبًا تصاعديًا.

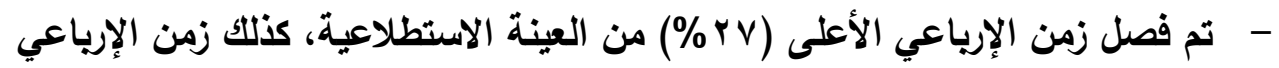
الأدنى (\% rv)

- - تم حساب متوسط زمن الإجابة من قبل التلاميذ في الإرباعي الأعلى، والتلاميذ في الإرياعي الأدنى. - - تم حساب الزمن اللازم للإجابة عن الاختبار. ويوضح الجدول الآتي بيان بالزمن اللازم للإجابة عن اختبار الثروة اللغوية كما يلي:

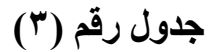
زمن اختبار الثروة اللغوية

\begin{tabular}{|c|c|c|c|}
\hline زمن الإجابة عن & 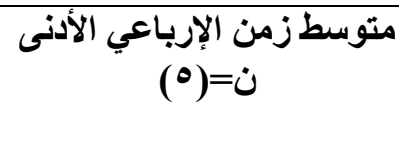 & 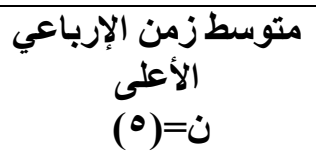 & المتغير \\
\hline هه دقيقة & rا دقيقة & \& د دقيقة & الزمن \\
\hline
\end{tabular}

يتضح من الجدول السابق أن متوسط زمن الإجابة عن الاختبار لمجموعتي

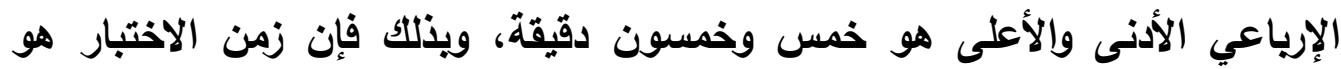
(ه0) دقيقة بالإضافة إلى (0) دقائق لقراءة التعليمات، وعلى ذلك فالزمن الكلي

$$
\text { للاختبار ستون دقيقة. }
$$

بلغت الدرجة النهائية لتصحيح الاختبار (0 ؛ ) درجة بحيث قدرت درجة الإجابة الصحيحة للسؤال بدرجة واحدة. 


$$
\text { ب-إعداد اختبار مهارات الخيال الإبداعي: }
$$

وقد تم الاستعانة بالعديد من المصادر في بناء الاختبار واشثتقاق مادته ومنها: - الاطلاع على البحوث والدراسات التي اهتمت بقياس الخيال الإبداعي (عبدالله،

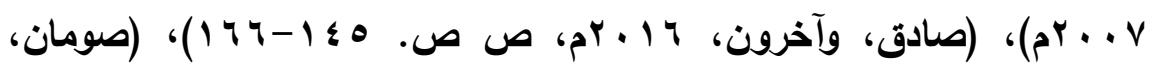

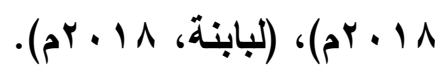

- ق قائمة مهارات الخيال الإبداعي وهي: الطلاقة، المرونة، الأصالة، الحيوية والتي

$$
\text { أ- الهبق تحديدها في الإطار النظري. }
$$

هذف هذا الاختبار إلى قياس الخيال الإبداعي لاى تلاميذ الصف الخامس الابتدائي الأزهري في مهارات (الطلاقة والمرونة والأصالة والحيوية).

$$
\text { ب-إعداد فقرات الاختبار: }
$$

في ضوء مهارات الخيال الإبداعي أعدات الباحثة اختبارًا مكونًا من سؤالين يتكون كل مفأل

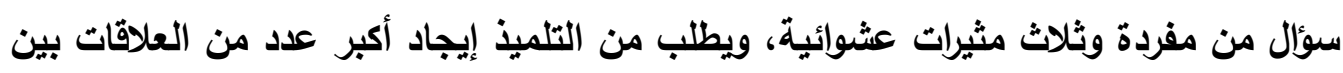

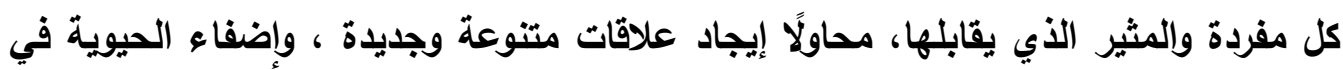

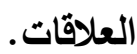

\section{ج- تحديد الأوزان النسبية وطريقة التصحيح:}

إن كل سؤال من أسئلة الاختبار يقيس المهارات الأريعة للخيال الإبداعي (الطلاقة،

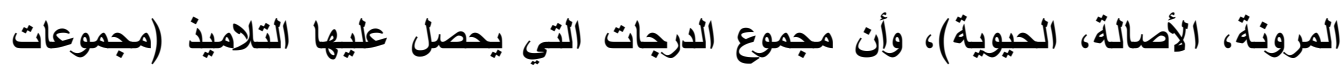
البحث) في إجابتهم على فقرات الاختبار تمثل درجة الإبداع الكلية للخيال الإبداعي.

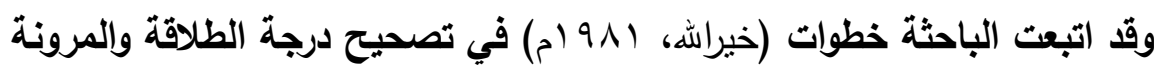
والأصالة والحيوية، وحسابهما وتحديدها على النحو التالي: 1 - حساب درجة الطلاقة: تمنح درجة واحدة لكل إجابة غير مكررة. ويذلك تكون الطلاقة لاى التلميذ تساوي عدد الأفكار التي كتبها. 
r -حساب درجة المرونة: يتم منح درجة واحدة للأفكار جميعها التي تنتمي إلى فئة واحدة. وتحسب درجات مرونة التلميذ بعدد الفئات التي نجدها في إجابته؛ لذا تكون دابه درجة المرونة بشكل عام أقل من درجة طلاقته.

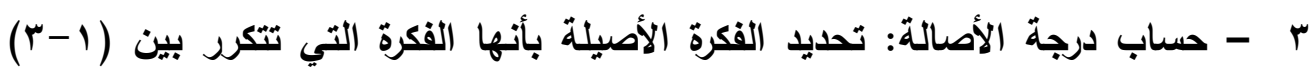

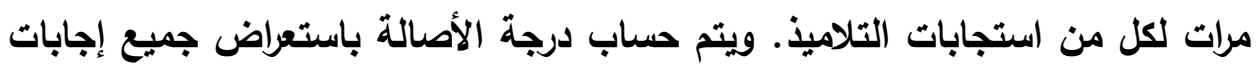
التلاميذ في الاختبار، ومنحهم درجات الطلاقة والمرونة والحيوية ويعد ذلك تم تصحيح درجة الأصالة بحيث: - - تمنح ثلاث درجات لكل فكرة تتكرر مرة وإحدة لكل من استجابات التلاميذ. - - تمنح درجتان لكل فكرة تتكرر مرتين لكل من استجابات التلاميذ. - - تمنح درجة واحدة فقط لكل فكرة تتكرر ثلاث مرات لكل من استجابات التلاميذ. - - تمنح درجة صفر إذا تكررت الأفكار أريع مرات فأكثر لكل من استجابات التلاميذ.

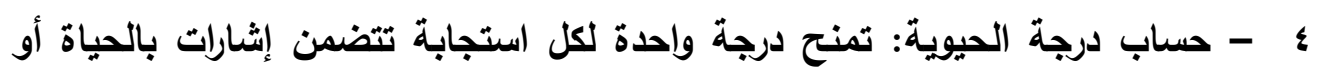
بالحركة. ه - حساب الارجة الكلية لمقياس الخيال الإبداعي: يتم حساب درجة الخيال الإبداعي عن طريق جمع درجات الطلاقة والمرونة والأصالة والحيوية.

$$
\text { د - حساب صدق الاختبار: }
$$

تم عرض الاختبار في صورته المبائية على مجموعة من المحكمين في مجال المناهج وطرق التدريس وعلم النفس؛ حيث طلب إليهم إبداء الرأي حول صحة الاختبار، وصياغة المفردات، ومناسبته للفئة العمرية التي تتناولها الدراسة، وقد تم الأخذ بمقترحاتهم وتم التعديل في ضوء تلك المقترحات وأصبح الاختبار في صورته النهائية. (ملحق رقم ؟)

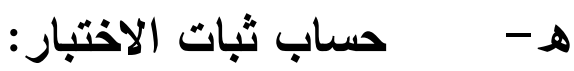

للتأكد من ثبات فقرات الاختبار استخدم الباحثة طريقة الاختبار وإعادة الاختبار

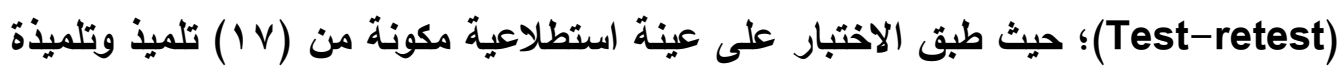
الصف الخامس الابتدائي بمعهد شبين القتاطر الابتدائي، ويعد أسبوعين من التطبيق الأول، تم تطبيقه للمرة الثانية على أفراد العينة الاستطلاعية نفسها، وقد تم حساب معامل ارتباط 
بيرسون بين التطبيق الأول والتطبيق الثاني على مهارات الخيال الإبداعي والارجة الكلية للاختبار والجدول التالي يوضح ذلك كالآتي:

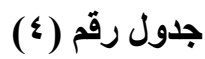

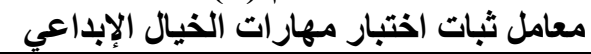

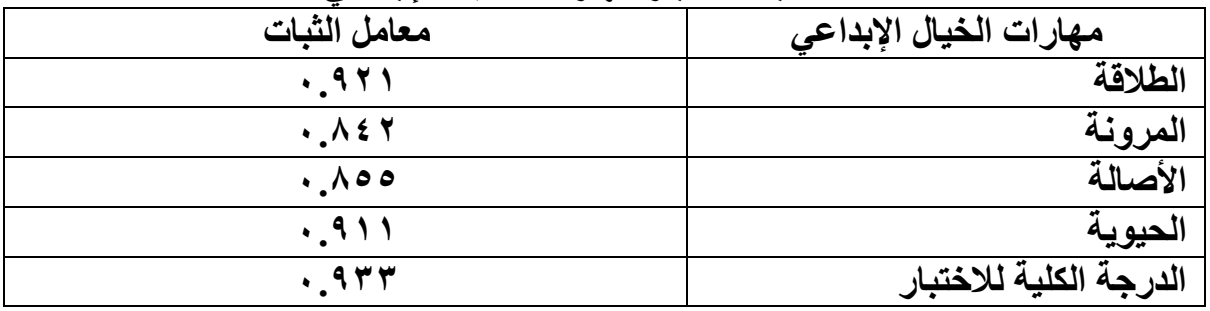

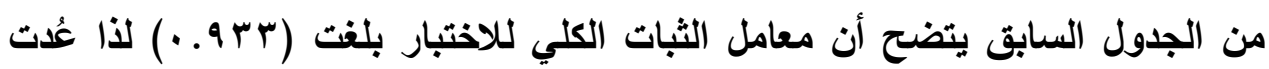
هذه القيمة ملائمة لغايات هذا البحث. ع - إعداد دليل المعلم لتدريس الموضوعات باستخدام استراتيجية الإثارة العثوائية: أعدت الباحثة دليل المعلم لكيفية تدريس موضوعات القراعة المقرة على تلاميذ الصف الخامس الابتدائي الأزهري في كتاب اللغة العربية باستخدام استراتيجية الإثارة العشوائية

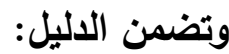

- - مفهوم استراتيجية الإثارة العشوائية ومميزاتها. - - إجراءات التدريس وفقًا لاستراتيجية الإثارة العشوائية. - الدرس معدة بالاستراتيجية المقترحة. ه-إعداد أوراق عمل التلميذ:

تم إعداد أورلق العمل بهدف مساعدة تلاميذ الصف الخامس الابتدائي الأزهري على تنفيذ الدروس في ضوء استراتيجية الإثارة العشوائية، وتحقيق أهدافها من خلال أدائهم للأنثطة والتدريبات المتضمنة؛ بهدف تنمية مفردات الثروة اللغوية ومهارات الخيال الإبداعي، وقد تضمنت الأوراق تحديد الدروس، الأهداف التعليمية، الأنشطة. 


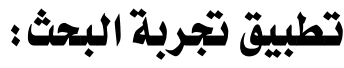 \\ وقد مر التطبيق الميداني للبحث بالمراحل التالية:

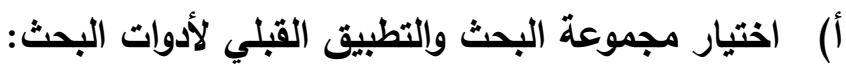

تم اختيار عينة البحث عشوائيًا من تلاميذ معهد شبرا الخيمة الابتدائي بلغ عددها (rی)

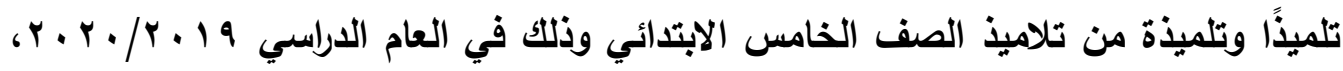
الفصل الدراسي الأول، وقسمت العينة إلى مجموعتين تجربية ويلغ عددها (9 1 () وضابطة بلغ عددها (19). (19).

وتم التطبيق القبلي لاختبار الثروة اللغوية ومقياس الخيال الإبداعي على مجموعتي البحث تطبيقاً قبلياً قبل التدريس؛ لتحديد مستوى التلاميذ فى اختبار الثروة اللغوية واختبار الخيال الإبداعي، حيث قامت الباحثة بزيارة المعهد والاتفاق مع الإدارة على تطبيق البحث بعد البدي الاطلاع على الموافقة الرسمية من قطاع المعاهد الأزهرية على تطبيق البحث.

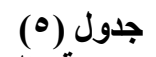

الفرق بين متوسطات درجات المجموعة التجريبية والمجموعة الضابطة في التطبيق القبلي وقيمة

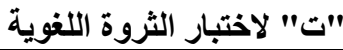

\begin{tabular}{|c|c|c|c|c|c|c|c|c|}
\hline \multicolumn{2}{|c|}{ مستوى الدلالة } & قيمة & الانحراف & المتوسط & العدد & التطبيق & المجموعة & الأداة \\
\hline \multirow[t]{2}{*}{ غير دالة } & \multirow[t]{2}{*}{$. r \leqslant 1$} & \multirow[t]{2}{*}{1.194} & $r . r \leq T$ & N.Y & 19 & قبلي & الضابطة & \multirow{2}{*}{ اللغوية } \\
\hline & & & $r . . \cdot v$ & $9 . \leqslant V$ & 19 & قبلي & التجريبية & \\
\hline
\end{tabular}

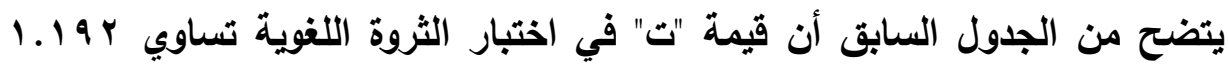

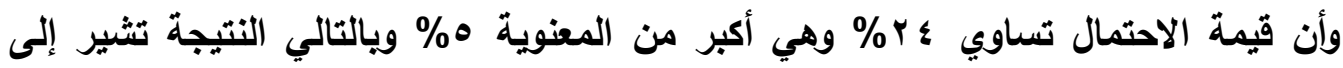
عدم وجود فروق ذات دلالة إحصائية بين متوسطي درجات المجموعة التجريبية والمجموعة المئ الضابطة في اختبار الثروة اللغوية مما يلال على تكافؤ المجموعتين. 


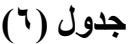

الفرق بين متوسطات درجات المجموعة التجريبية والمجموعة الضابطة في التطبيق القبلي وقيمة

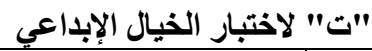

\begin{tabular}{|c|c|c|c|c|c|c|c|c|}
\hline \multicolumn{2}{|c|}{ مستوى الالالة } & \multirow{3}{*}{ 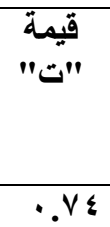 } & \multicolumn{2}{|c|}{ المجموعة التجريبية } & \multicolumn{2}{|c|}{ المجموعة الضابطة } & \multirow{2}{*}{ أبعقاد } & \multirow[t]{2}{*}{ الأداة } \\
\hline & & & الانحراف & المتوسط & الاتحراف & المتوسط & & \\
\hline غير دالة & $. . \leqslant 7 \leqslant$ & & $1 . \wedge r 0$ & $\varepsilon . \& Y$ & $1.77 \mathrm{~V}$ & $\varepsilon \ldots$ & الطلاقة & اختبار \\
\hline غير دالة & $1 . \cdots$ & $\because \cdots$ &. $.7 \wedge \varepsilon$ &. .74 &. $.7 \wedge \varepsilon$ & .94 & المرونة & الخيال \\
\hline غير دالة &. .191 & $.0 \wedge r$ &. .297 &.$V r$ &. $.71 r$ &..$\leqslant V$ & الأصالة & الإبداعي \\
\hline غير دالة & .09 &. .11 & .9 .0 & $1.2 V$ & $\cdot .9 \cdot r$ & $1 . \leqslant Y$ & الحيوية & \\
\hline غير دالة & $1 \ldots$ & $\because \leqslant \leqslant r$ & $r .9 \leq r$ & $7 . \wedge 9$ & $r .91 r$ & $7 . \leqslant V$ & ككل المقياس & \\
\hline
\end{tabular}

ويتضح أن قيمة "ت" في التطبيق القبلي لاختبار الخيال الإبداعي تساوي بـ ؛ـ . ، وأن قيمة الاحتمال تشاوي (1) وهي أكبر من المعنوية ه\% ويالتالي النتيجة تشبر إلى عدم وجود فروق ذات دلالة إحصائية بين متوسطي درجات المجموعة التجريبية والمجموعة الضابطة في اختبار الخيال الإبداعي مما يدل على تكافؤ المجموعتين. ب) التدريس للمجموعات: تم تدريس موضوعات القراعة المختارة من مقرر اللغة العربية "الفصل الاراسي الأول" لتلاميذ الصف الخامس الابتدائي الأزهري باستخدام استراتيجية الإثارة العشوائية للمجموعة

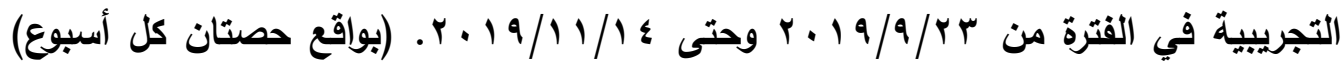
باستخدام دليل المعلم المعد، ويذلك استغرقت تجربة البحث عدد (N) أسابيع، حيث استغرق التطبيق القبلي لاختبار الثروة اللغوية، واختبار الخبال الإبداعي الأسبوع الأول، بينما تم إجراء التطبيق البعدي لاختبار الثروة اللخوية، واختبار الخيال الإبداعي خلال الأسبوع الأخير، ويذلك فعدد أسابيع التدريس الفعلي هي ستة أسابيع؛ بينما تدرس المجموعة الضابطة بالطريقة

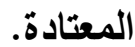

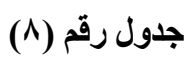

الموضو عات المختارة والتوزيع الزمني لها

\begin{tabular}{|c|c|c|c|}
\hline عدد الحصص & عدد الأستابيع & الموضوعات & ? \\
\hline$\varepsilon$ & أسبو عان & حب الوطن & 1 \\
\hline$\varepsilon$ & أسبو عان & الكهرباء في حياتنا & $r$ \\
\hline$\varepsilon$ & أسبو عان & تربية الدواجن & $r$ \\
\hline Ir & ستة أسابيع & المجموع & \\
\hline
\end{tabular}


يتضح من الجدول أن الددة الزمنية للتدريس استغرقت ستة أسايبع بواقع اثثتا عشرة حصة

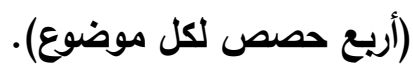
ج) تطبيق الأدوات تطبيقاً بعدياً: بعد التريس للجموعتي البحث، تم تطبيق اختبار الثروة اللغوية واختبار مهارات الخيال الإبداعي تطبيقاً بعديا على المجموعتين التجريبية والضابطة للوقوف على الفروق بين التطبيقين والتعرف على مدى فعالية البرنامج على أداء واتجاهات التلاميذ مجموعة الدراسة. د) المعالجة الإحصائية: تم استخدام حزمة البرامج الإحصائية (Spss)، حيث تم الاستعانة بمعادلة الارتباط بيرسون؛ وذلك لحساب ثبات اختبار الثروة اللغوية، واختبار الخيال الإبداعي، والاستعانة بالمتوسطات الإنات

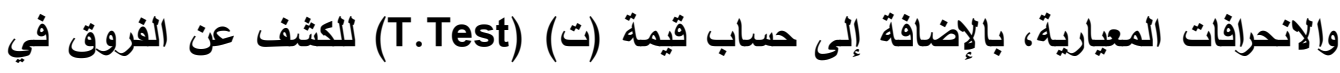

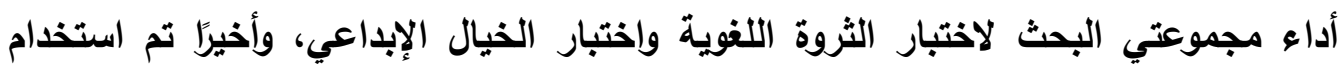
مريع إيتا؛ لحساب حجم تأثير الوحدة على التلاميذ.

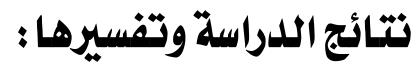
يتم عرض نتائج الدراسة ومناقشتها، وفقاً لتساؤلاتها وما يتعلق بها من فروض وذلكك

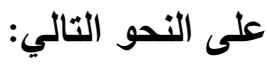
- للإجابة عن التساؤل الأول ونصه: ما المفردات اللغوية المناسبة لتلاميذ الصف الخامس

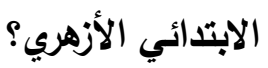

فقد تم الإجابة عنه في ثنايا إجراعات الدراسة سابقة الأكر وذلك من خلال إعداد قائمة المفردات اللغوية اللازمة لتلاميذ الصف الخامس الابتدائي الأزهري. - وللإجابة عن التساؤل الثانى ونصه :"ما مهارات الخيال الإبداعي المناسبة لتلاميذ الصف الإنف الخامس الابتدائي الأزهري؟ قامت الباحثة بتحليد مهارات الخيال الإبداعي كما هو موضح الإنها سابقاً. - وللإجابة عن السؤال الثالث والرابع ونصهما: 1- ما فاعلية استراتيجية الإثارة العشوائية في تنمية الثروة اللغوية لاى تلاميذ الصف

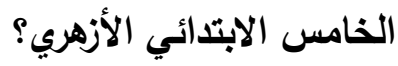


r- ما فاعلية استراتيجية الإثارة العثوائية في تنمية مهارات الخيال الإبداعي لاى تلاميذ

الصف الخامس الابتدائي الأزهري؟

ويهدف الإجابة عنهما تم التحقق من فروض الاراسة الإحصائية كما يلي:

النتائج المتعلقة بتنمية الثروة اللفورة :

أولاً: نتائج الفرض الأول:

ينص هذا القرض على أنه:

- يوجد فرق ذو دلالة إحصائية عند مستوى (1 (..) بين متوسطي درجات المجموعة

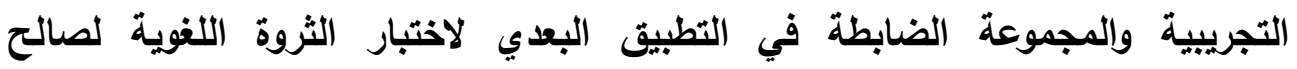

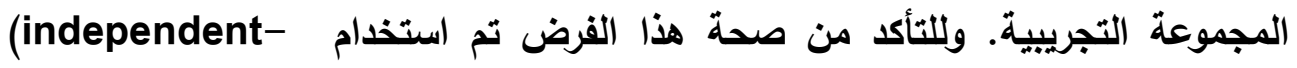
samples T-test)

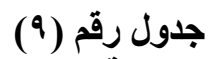

الفرق بين متوسطات درجات المجموعة التجريبية والمجموعة روة الضابطة في التطبيق البعدي لاختبار

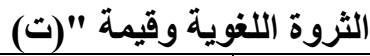

\begin{tabular}{|c|c|c|c|c|c|c|c|}
\hline \multicolumn{2}{|c|}{ مستوى الدلالة } & قيمة (ت) & الانحراف & المتوسط & العدد & التطبيق & المجموعة \\
\hline \multirow[t]{2}{*}{ دالة } & \multirow[t]{2}{*}{$\because \cdots$} & \multirow[t]{2}{*}{ I Y.VAV } & $\varepsilon .119$ & ro.11 & 19 & بعدي & الضابطة \\
\hline & & & P.rTo & $\varepsilon \cdot .7 r$ & 19 & بعدي & التجريبية \\
\hline
\end{tabular}

يتضح من الجدول السابق وجود فرق ذي دلالة إحصائية بين متوسطي درجات

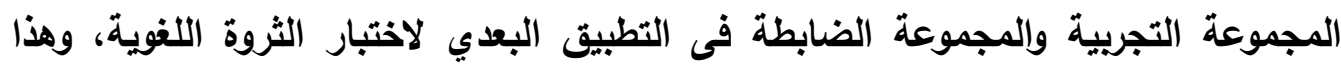
الفرق لصالح المجموعة التجريبية؛ حيث بلغ متوسط التطبيق البعدي للمجموعة التجريبية

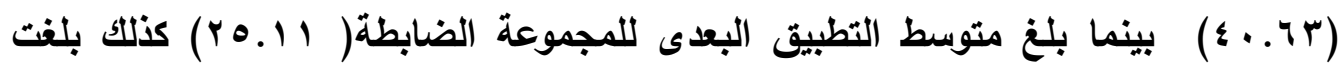

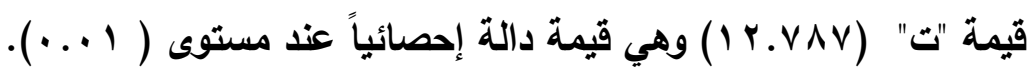
strength effect) وإستكمالاً للتحقق من صحة الفروض الأول تم حساب حجم التأثير

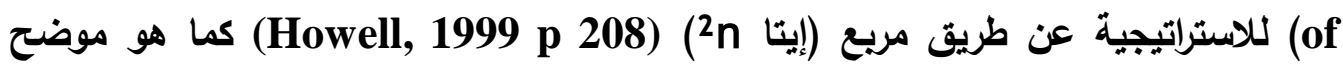

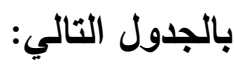




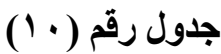

قيمة (n 2) وقيمة (d) المقابلة لها ومقدار حجم التأثير

\begin{tabular}{|c|c|c|c|}
\hline مقدار حجم التأثير & قيمة (d ) & قيمة إيتا (nn & قيمة (t) \\
\hline كبير & \&. Yo & $\cdot .119$ & I Y.VAV \\
\hline
\end{tabular}

يتضح من الجدول السابق أن قيمة (d) الناتجة أعلى من القيمة المطلوية مما يدل على

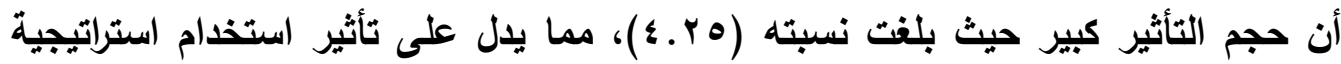
الإثارة العشوائية فى تنمية الثروة اللغوية لتلاميذ الصف الخامس الابتذائي الأزهري، ويذلك يمكن القول بأن الاستراتيجية المستخدمة قد أسهمت في تنمية الثروة اللغوية بنسبة كبيرة؛ وقا يرجع ذلك إلى أن:

• فاعلية استراتيجية الإثارة العشوائية جعل التلاميذ في موقف جيد ومتفاعل مع الدرس اعتمادًا على تنوع الإجابات وتثنعبها وكثرتها، بدلًا عن الموقف غير المتجدد الأي يعتمد على الطريقة الاعتيادية. • ممارسة أنشطة الإثارة العشوائية ساعد التلاميذ من فهم المادة المقروية واستيعابها بما فيها من صيغ وعبارات وأساليب، مما أدى إلى تنمية ثروتهم اللغوية. • لاحظت الباحثة أن استراتيجية الإثارة العشوائية ساعد على شد انتباه التلاميذ وإثارة

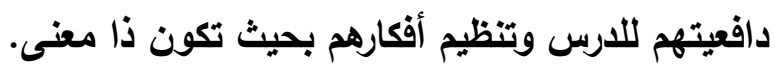
• ممارسة الإثارة العشوائية قـ أثرى التلاميذ بالكثير من المفردات، وعمل على تتمية الإبداع من خلال استخدام القنون البلاغية التي تأتي من محاولة الربط بين الكلمات العشوائية. وتعد هذه النتيجة تعزيزاً لنتائج الدراسات السابقة التى اهتمت بتنمية الثروة اللغوية، والتي توصلت لتنمية الثروة اللغوية باستخدام أساليب ويرامج واستراتيجيات مختلفة كما في دراسة

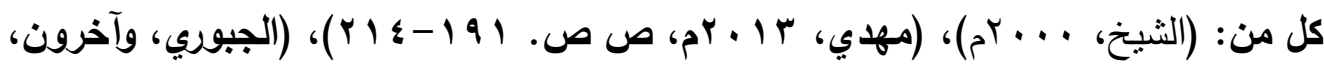
(VTr-VHO. 
النتائج المتعلقة بتنمية الخيال الإبلداعي: ثالثاً: نتائج الفرض الثاني: ينص هذا الفرض على أنه: - يوجد فرق ذو دلالة إحصائية عند مستوى (1 (..) بين متوسطي درجات المجموعة

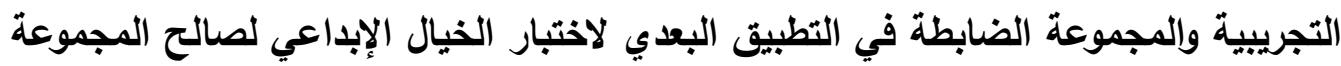
التجريبية.

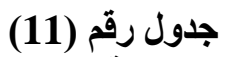

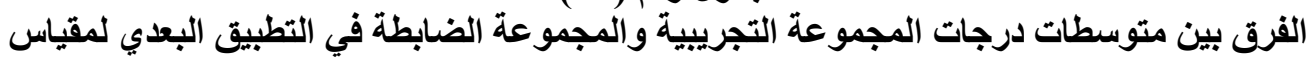

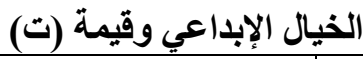

\begin{tabular}{|c|c|c|c|c|c|c|c|}
\hline \multirow{2}{*}{\multicolumn{2}{|c|}{ مستوى الدلالة }} & \multirow{3}{*}{ قيمة (ت) } & \multicolumn{2}{|c|}{ المجوعة التجريبية } & \multicolumn{2}{|c|}{ المجموعة الضابطة } & \multirow{3}{*}{ الإبداريال } \\
\hline & & & الإنحراف المعياري & المتوسط & الإنحراف المعياري & المتوسط & \\
\hline دالة & $\because \cdots$ & & $r_{.} . \Delta r$ & $\mid r .11$ & $1 . V \leq r$ & $\varepsilon .01$ & \\
\hline دالة & $\because \cdots$ & $11 .+10$ & 1.91 & r.^s &. $.7 \wedge \varepsilon$ & .94 & المرونة \\
\hline دالة & $\therefore \cdots$ & $9.7 \% 4$ & 1.911 & Y.19 &. .297 &.$r v$ & الأصالة \\
\hline دالة & $\because \cdots$ & 11.VAr & 1.517 & $0 . \varepsilon r$ & $\because V \vee r$ & 1.04 & الحيوية \\
\hline دالة & $\because \cdots$ & $10 . Y \wedge$. & $r . r \leq 4$ & TY.YT & r.79r & V.19 & ككلرات \\
\hline
\end{tabular}

يتضح من الجدول السابق وجود فرق ذى دلالة إحصائية بين متوسطي درجات المجموعة التجربية والمجموعة الضابطة فى التطبيق البعدي لاختبار الخيال الإبداعي، وهذا الفرق لصالح المجموعة التجريبية؛ حيث بلغ متوسط التطبيق البعدي للمجموعة التجريبية

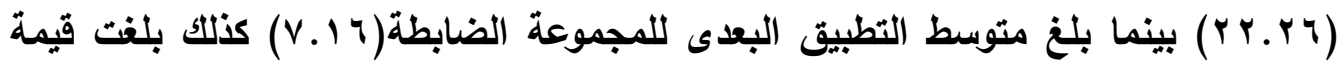

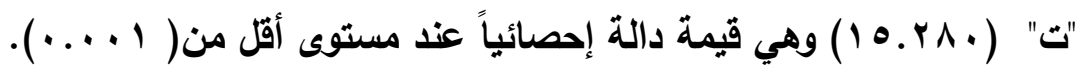


Strength effect)(استكمالاً للتحقق من صحة الفروض الثاني تم حساب حجم التأثير

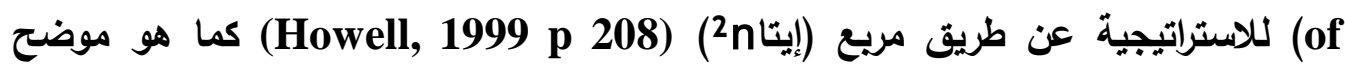

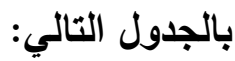

جدول رقم (12) - (12)

قيمة (n²) وقيمة (d) المقابلة لها ومقدار حجم التأثير

\begin{tabular}{|c|c|c|c|c|}
\hline مقدار حجم التأثير & قيمة (d) & $\begin{array}{c}\text { قيمة إيتا } \\
\left(n^{2}\right)\end{array}$ & "t" قيمة & مهارات الخيال \\
\hline كبير & $\varepsilon \ldots$ & $\cdot \Lambda \cdot \varepsilon$ & $|r.| \wedge \Lambda$ & الطلاقة \\
\hline كبير & r.TV &.$v V 1$ & $11 . .40$ & المرونة \\
\hline كبير & Y. & $.0 \leq 9$ & ד.7 & الأصالة \\
\hline كبيز & $r .9 r$ & $\because \vee \vee q \leq$ & 11.VAr & الحيوية \\
\hline كبير & $0 . .1$ & . & $10 . Y \wedge$. & المهارات ككل \\
\hline
\end{tabular}

يتضح من الجدول السابق أن قيمة (d) الناتجة أعلى من القيمة المطلوية مما يدل على

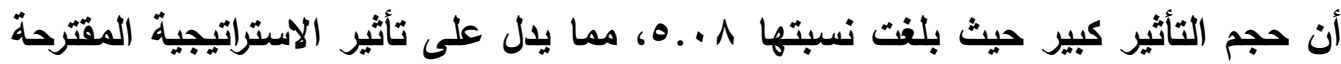
على تنمية مهارات الخيال الإبداعي لاى تلاميذ الصف الخامس الابتائي الأزهري، ويذلك يمكن القول بأن استراتيجية الإثارة العشوائية قد أسهمت في تنمية مهارات الخيال الإبداعي الإبي الإسي بنسبة كبيرة، مما يال على تأثير الاستراتيجية فى تنمية مهارات الخيال الإبداعي لاى تلاميذ

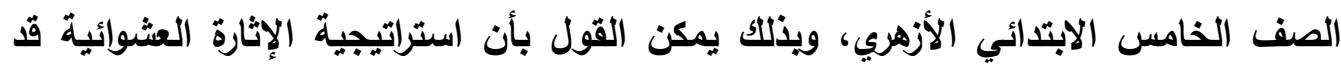
أسهمت في تنمية مهارات الخيال الإبداعي بنسبة كبيرة. وقد ترجع هذه النتائج إلى العوامل التالية: • إن استراتيجية الإثارة العشوائية نقلت التلاميذ من النمط التقليدي إلى نمط جديد مبني على العمليات العقلية، وجعلت التلميذ محور العملية التعليمية وأتاحت لهم الإنات ممارسة الحوار والمناقشة، وعرض أفكارهم بحرية، وتبادل الأفكار مع زملائهم. 
• احترام المعلم لاستجابات التلاميذ واستفسارتهم وخيالاتهم، وتشجيع استجاباتهم غير المكتملة، والابتعاد عن الانتقادات الجارحة وإلتعليقات؛ مما ترتب عليه دعم تقتهم بأنفسهم وتثجيعهم على الاندماج النشط لإعمال العقل والتصور الأهني، وعدم التردد في التعبير عن خيالهم وأفكارهم وجعلهم يستشعرون قيمة إبداعهم وقدرتهم على الخيال والانطلاق الفكري. • إنجاز التلاميذ للمهام والأنشطة المختلفة، أسهم في إضفاء جو من المرح والمتعة بين التلاميذ. • ومن الملاحظات أثناء التطبيق - والتى قد تكون أحد الأسباب التي يمكن إرجاع النتائج إليها- أن التلاميذ كان لايهم حماساً وميلاً لتجريب استرتيجية غير مألوفة لايرهم. وتتفق الدراسة الحالية فى نتائجها ميع نتائج العديد من الدرسات والبحوث السابقة مثل

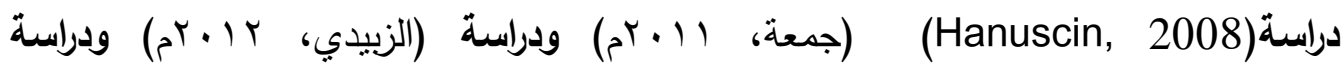

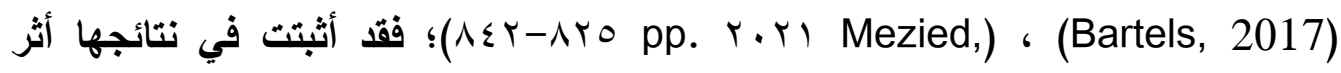
استراتيجية الإثارة العشوائية على المهارات المختلفة. في ضوء النتائج التى توصل إليها البحث الحالي يمكن استنتاج ما يأتي:

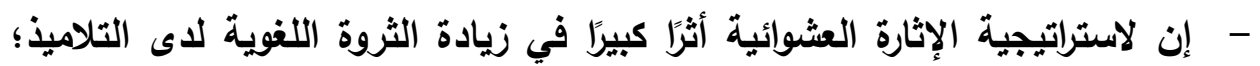
نتيجة استعمال الفنون البلاغية للريط بين الميثرات العشوائية أثناء العديث وإلكتابة مما أدى إلى رفع قدرتهم اللغوية. - - إن استخدام استراتيجية الإثارة العشوائية عوَّد التلاميذ على الملاحظة الدقيقة لما

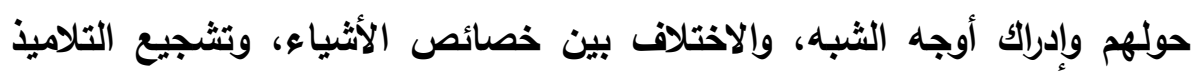

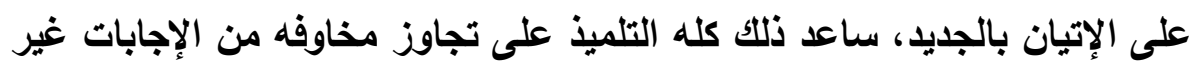

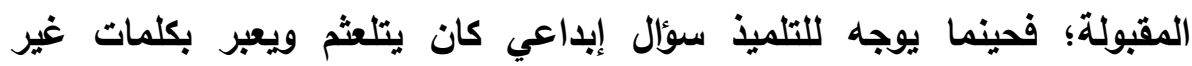
مفهومة. - شكلت أنثطة الإثارة العشوائية نشاطًا لغويًا وظيفيًا وجد مكانه الطبيعي في خبرات التلاميذ اليومية والمواقف الحياتية. 
- - لاحظت الباحثة حماسة التلاميذ إلى التدريس باستخدام استراتيجيات تدريسية لم

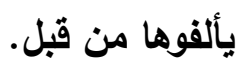

\section{توصيات البحث ومقتزحاته :}

في ضوء ما توصل إليه البحث من نتائج، توصي الباحثة بمجموعة من التوصيات التي تأمل أن تؤخذ بعين الاعتبار والاستفادة منها وتتمثل هذه التوصيات فيما يلي:

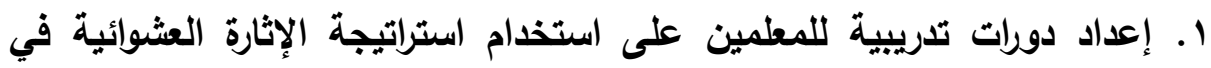

$$
\text { التدريس. }
$$

r. توفير العديد من البرامج الإثرائية لتنمية مهارات الخيال الإبداعي لدى تلاميذ

$$
\text { المرحلة الإبتدائية. }
$$

r. تضمين الكتب المقرة على المرحلة الابتدائية الأزهرية أنشطة لتنمية الخيال

$$
\text { الإبداعي. }
$$

ء. تقديم التوجيهات والأمثلة التطبيقية في أدلة المعلم التي تساعده في استخدام

$$
\text { استراتيجية الإثارة العشوائية في التدريس. }
$$

ه. تطوير أساليب ووسائل التقويم، والاهتمام بالتقويم المستمر وتنوعه بحيث يشمل

$$
\text { الجوانب المهارية والوجدانية بجانب الجوانب المعرفية. }
$$

المقترحات:

برنامج إثرائي لتنمية الثروة اللغوية لتلاميذ المرحلة الابتدائية الأزهرية. ل استراتيجية مقترحة لتنمية الخيال الإبداعي لاى تلاميذ التعليم الأساسي. ل إجراء دراسة عن معوقات تنمية الخيال الإبداعي لاى التلاميذ. 


\section{المراجع}

إبراهيم فريج حسين محمد(7 ( • rم): فاعلية استخدام استراتيجية الإثارة العشوائية في تتمية بعض مهارات الطلاقة التعبيرية لاى المتعلمين بالمرحلة الإعدادية، دراسات عربية في التربية وعلم

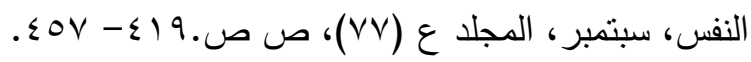
إبراهيم محمد محمود علي (10 • r م): مقال عن الثروة اللغوية القرآنية، مجلة العلوم التربوية،

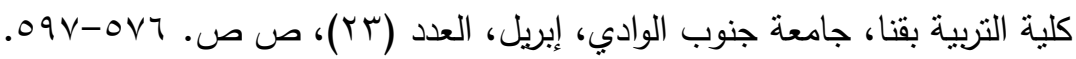

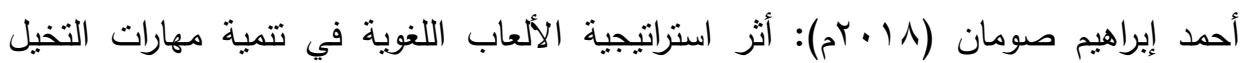
الإبداعي لدى أطفال الروضة في مدينة عمان [دفتر اليومية]: المجلة الدولية لنطوير التفوق،

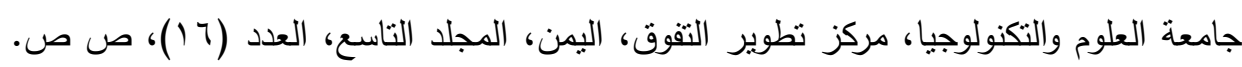
$. \vee \Upsilon \neg-\Sigma q$

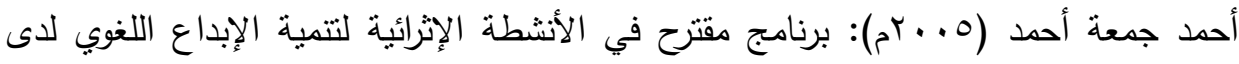

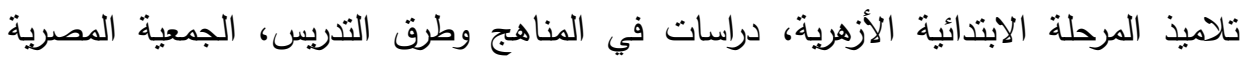

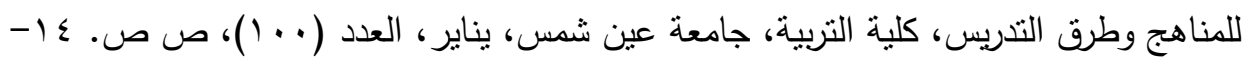
. «

أحمد محمد المعتوق (799 (م): الحصيلة اللغوية، أهيتها، مصادرها، وسائل تتميتها، سلسلة

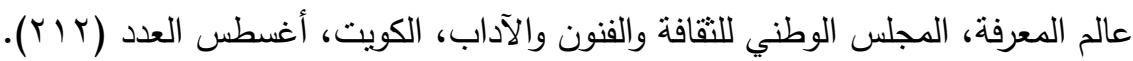
اسبرنس سابا سليم قطيمي(9 + . rم): أثر استخدام الخيال في تتمية التفكير الإبداعي والتحصيل لاى طلبة الصف الخامس الأساسي في محافظة بيت لحم، رسالة ماجستير، عمادة الدراسات

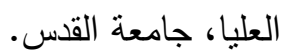
أمل محمد حسونة، شيرين محد دسوقي، محمد علي مصطفى، شيماء أحمد

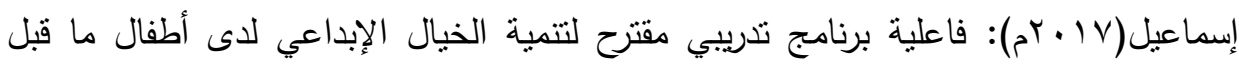

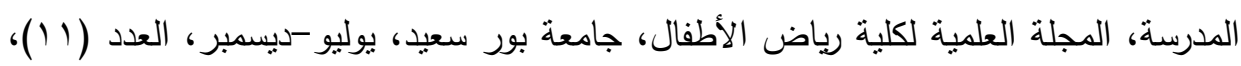

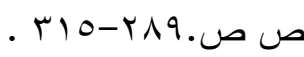

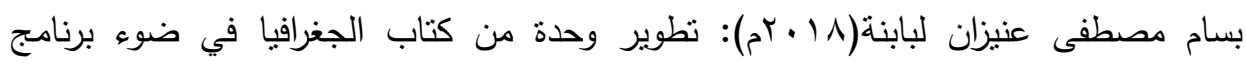

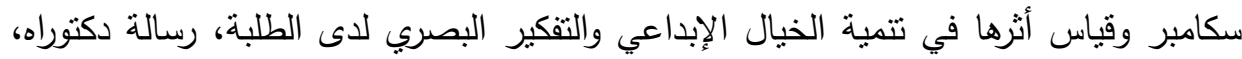
كلية التربية، جامعة اليرموك، الأردن. ثناء عبدالمنعم رجب حسن (^ . . rم): أثز استراتيجية مقترحة في التفكير البصري على تتمية

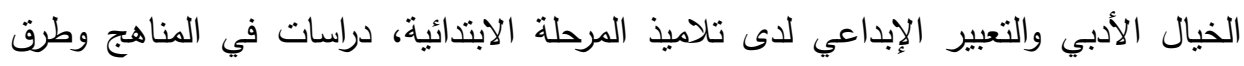


التدريس، الجمعية المصرية للمناهج وطرق التدريس، كلية التربية، جامعة عين شمس، أبريل،

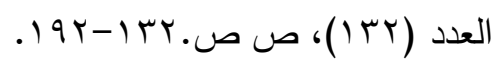

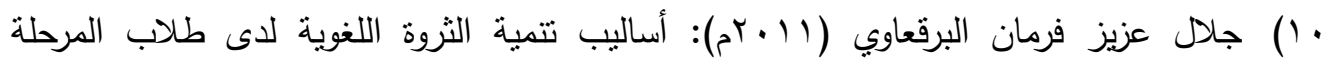
الثانوية من وجهة نظر مدرسي اللغة العربية، مجلة العلوم الإنسانية، كلية التربية للعلوم

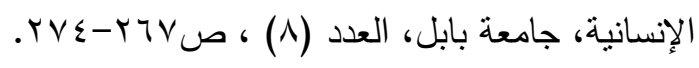

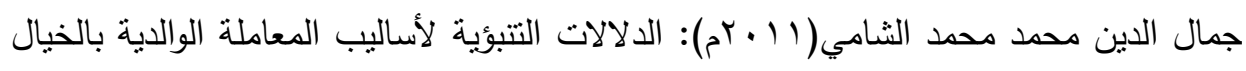

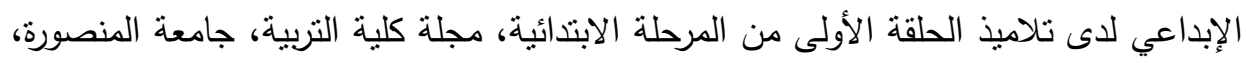

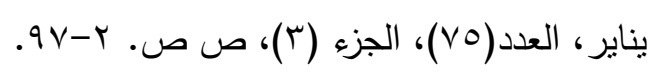

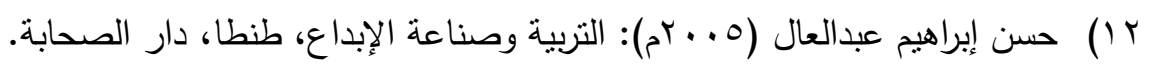

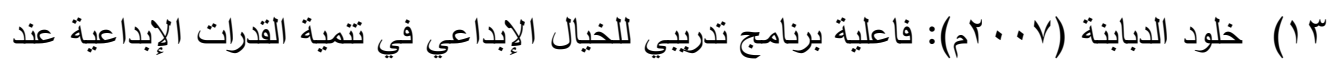

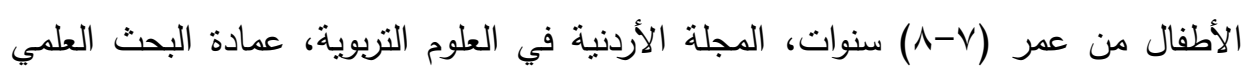

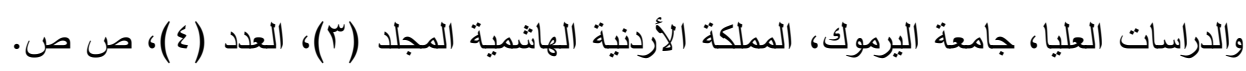
זדז-ז人ז. ع () ذوقان عبيدات، سهيلة أبو سميد (0. . rم): الدماغ والتعلم والتفكير، عمان، الأردن، دار ديبو للنشر د

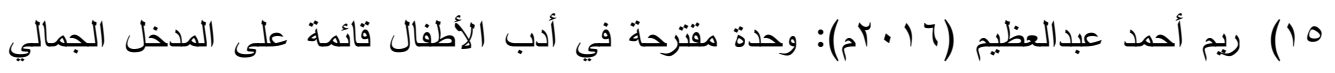

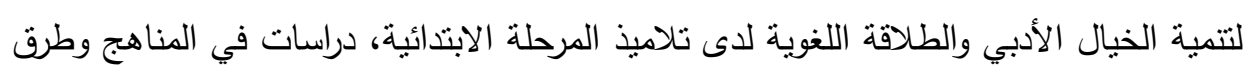

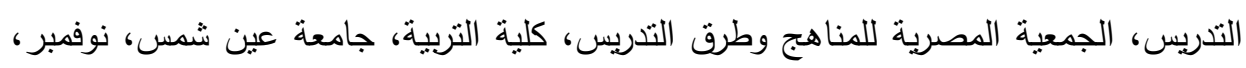

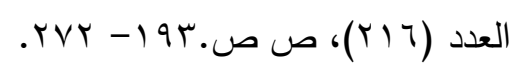

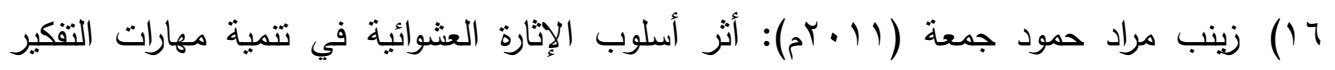
الإبداعي والأداء التعبيري لدى طالبات الصف الخامس الأدبي، رسالة ماجسنير، كلية التربية

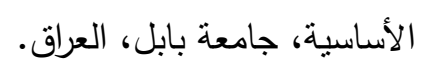

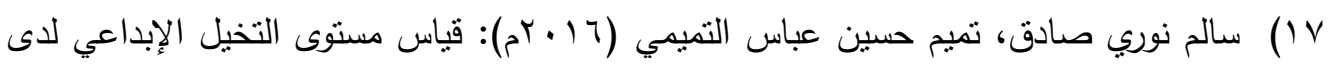

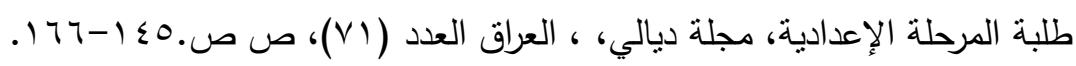

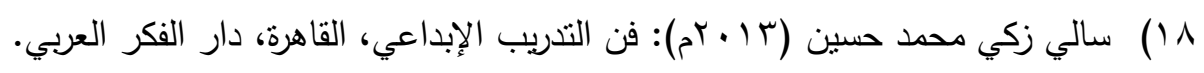

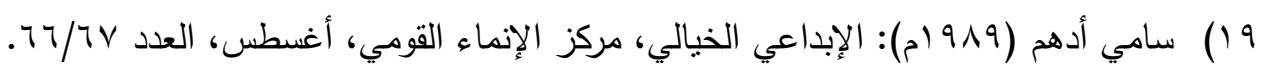

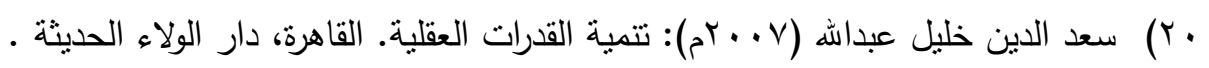




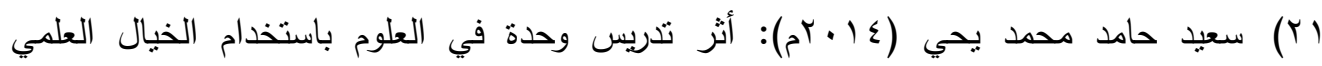

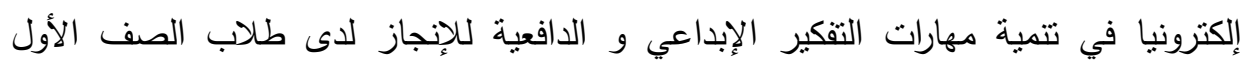

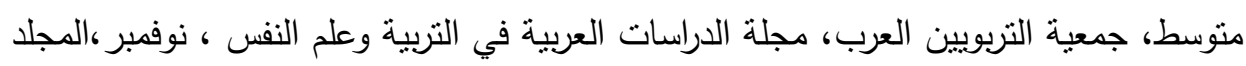
.$(00)$

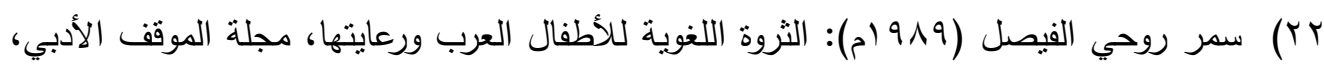

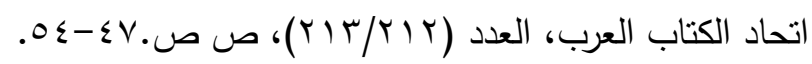

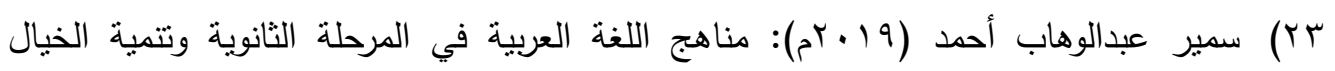

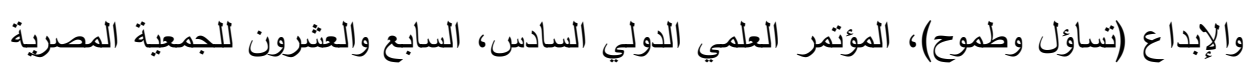

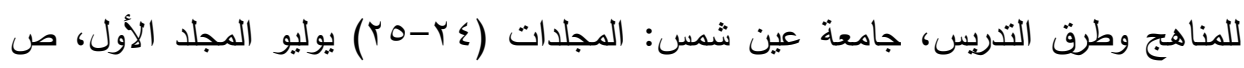

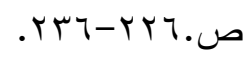

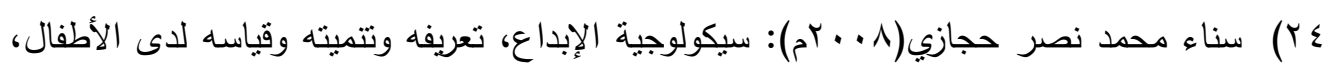

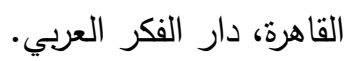

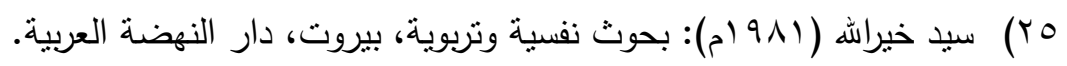

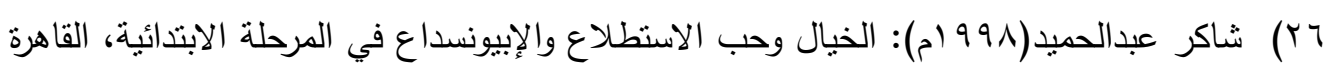

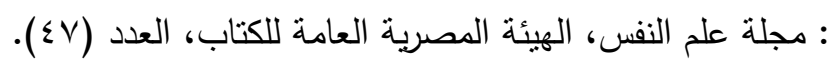

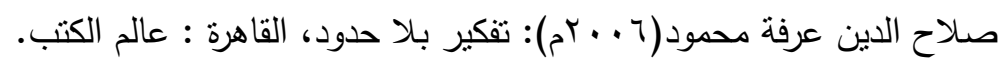
(rV

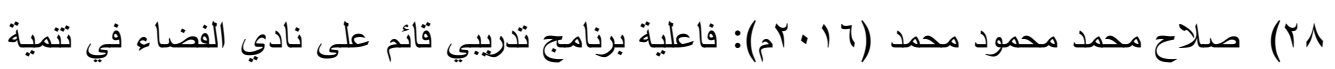
الخيال لدى الأطفال، مجلة دراسات عربية في التربية وعلم النفس، العدد (Y) (Y)، مارس.

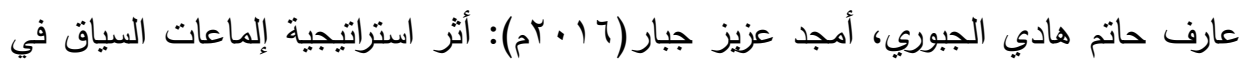
(rq

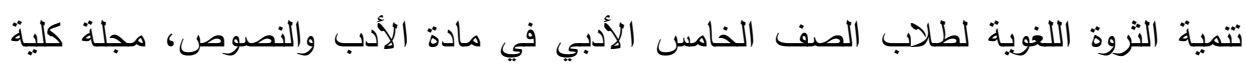

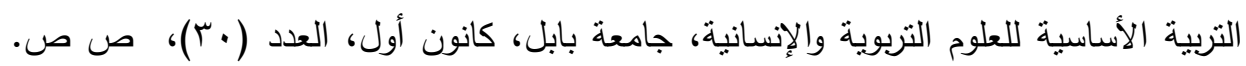
.VTH-VTO

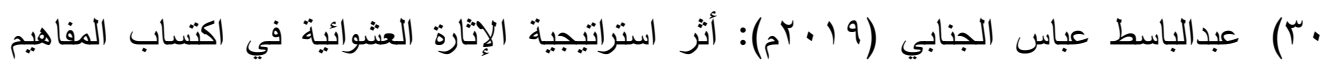

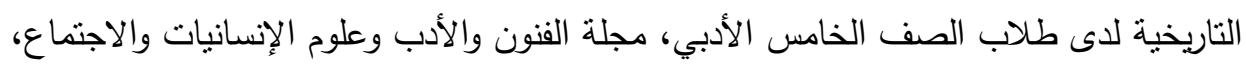

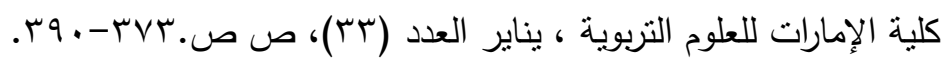

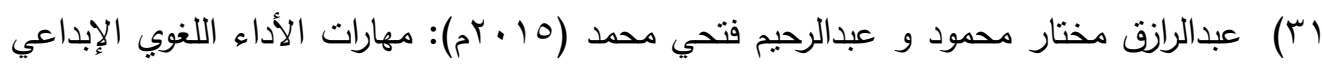

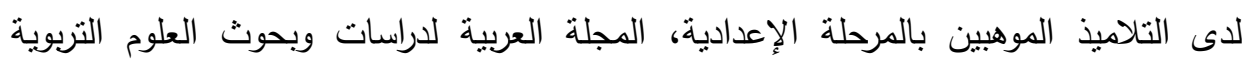


والإنسانية، مؤسسة د. حنان درويش للخدمات اللوجستية والتعليم النطبيقي، المجلا ع (؟)، ص ص. •

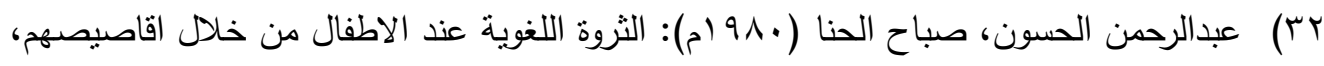

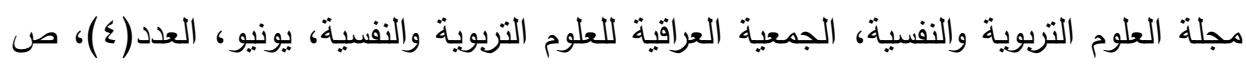
ص.

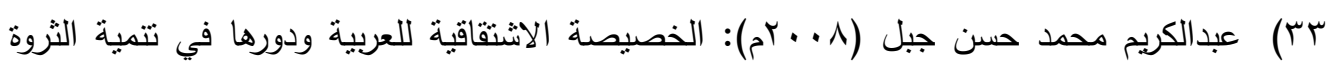
اللغوية وفقهها، المؤتمر الدولي: اللغة العربية والتتمية البشرية : الواقع مركز الدراسات والبحوث الاتئه

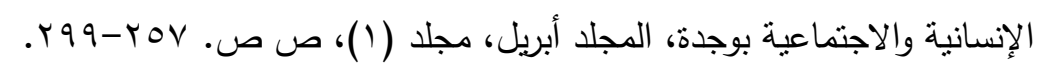

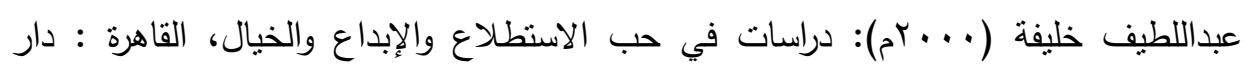

غريب للنشر والتوزيع.

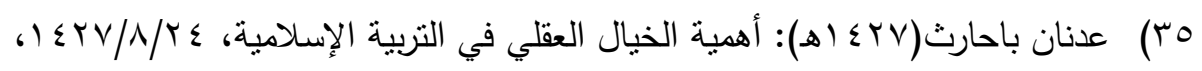
http://bahareth.org/index.php?browse=article\&id=10274.

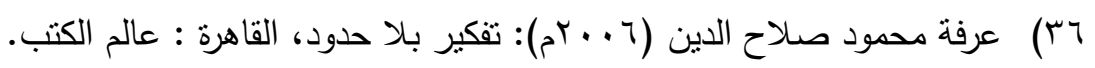

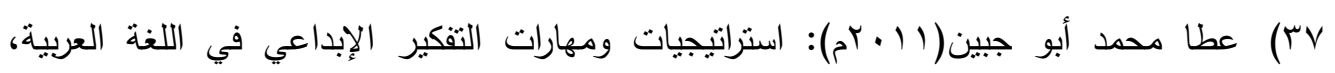
تطبيقات عملية، الكويت: مكتبة الفلاح للنشر والتوزيع.

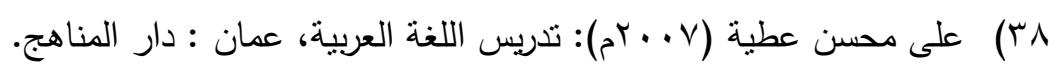

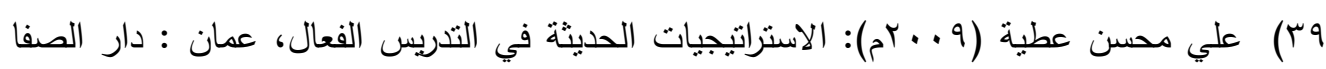
للطباعة. • ـ) فتحي علي يونس، حسن سيد شحاتة (1 ( • بم): التحليل الصرفي وعلاقته بتتمية الثروة اللغوية

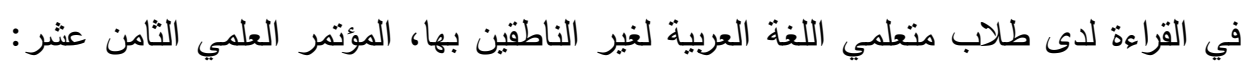

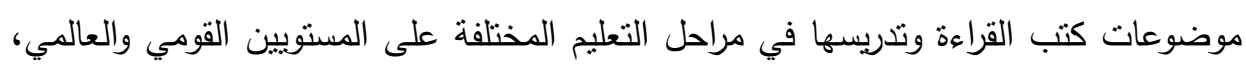

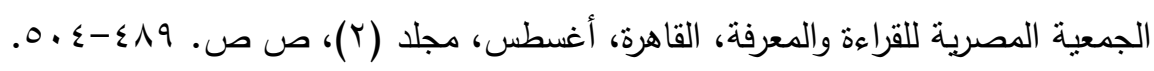

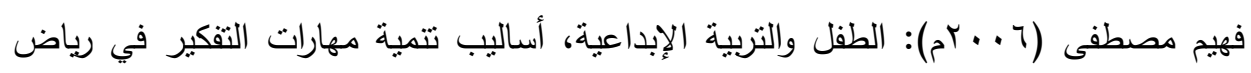
الأطفال والمدرسة الابتدائية. القاهرة، دار الفكر العربي.

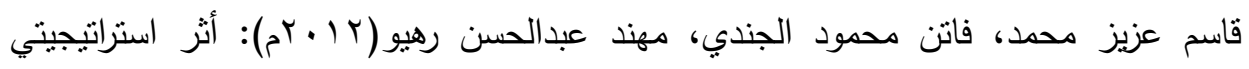
$(\varepsilon r$

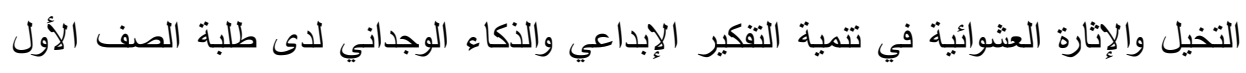

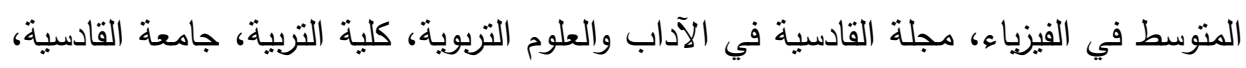

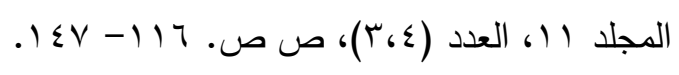




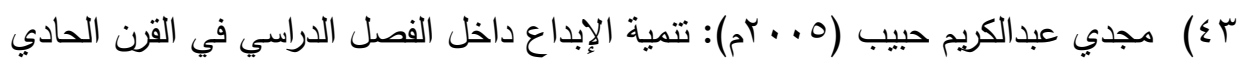

$$
\text { والعشرين. القاهرة، دار الفكر العربي. }
$$

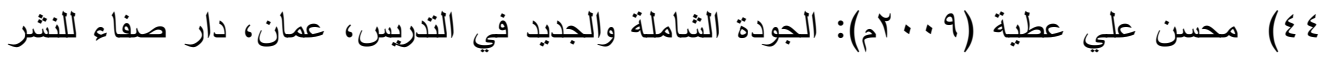
والتوزيع.

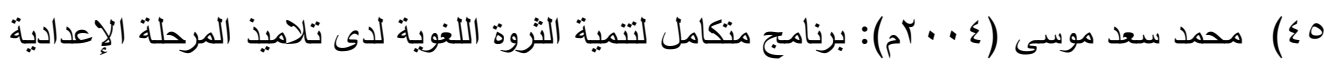
الأزهرية من خلال أبواب المشترك والترادف والاثتقاق في الدرس القرائي، رسالة دكثوراه، كلية التربية بكفر الثيخ، جامعة طنطا.

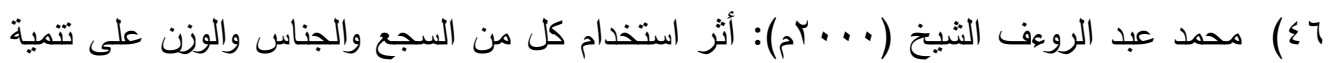

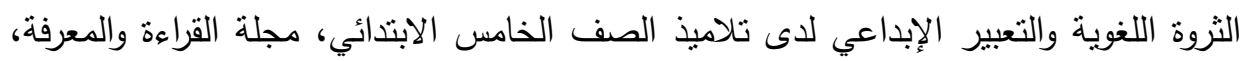

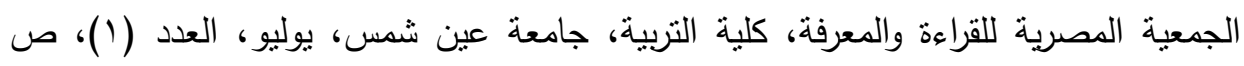
ص. . . محمود رشدي خاطر، مصطفى رسلان (·. . rم): تعليم اللغة العربية والتربية الدينية، القاهرة،

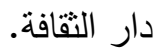

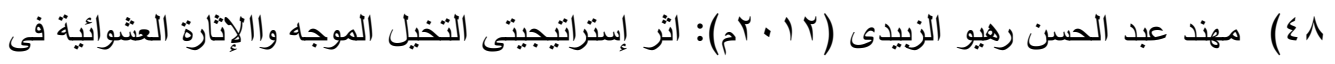

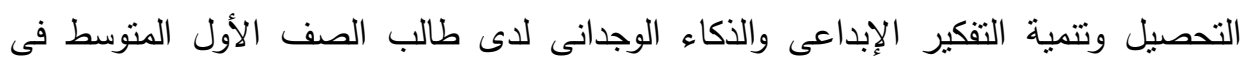
الفيزياء، رسالة دكتوراه، كلية التربية، جامعة بغداد، العراق.

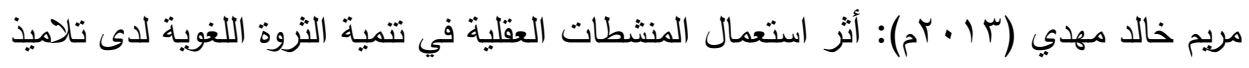
$(\leqslant 9$

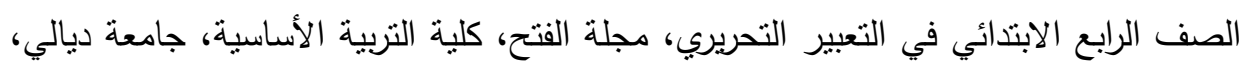

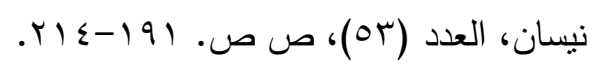

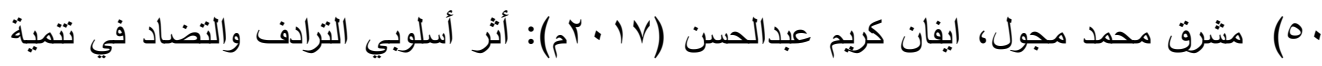
الثروة اللغوية في مادة المطالعة والنصوص لدى طالبات الصف الثناني المتوسط، مجلة كلية

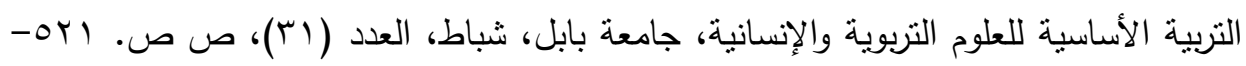
$.0 \leqslant 9$

مصري عبدالحميد حنورة (ץ+. +rم): الإبداع وتتميته من منظور تكاملي، القاهرة، مكتبة الأنجلو المصرية، طن. ror) مصري عبدالحميد حنورة (999 (م): منظومة السلوك الإبداعي في مرحلة الطفولة، مجلة الطفولة العربية، العدد الصفري. ro) مدوح عبدالمنعم الكناني (11 + rم): سيكولوجية الطفل المبدع، عمان، دار الميسرة. 
ـ 0) هالة سعيد عبدالعاطي أبوالعلا (9 ( ب م): تأثثر استراتيجيتي الإثارة العشوائية وحدائق الأفكار

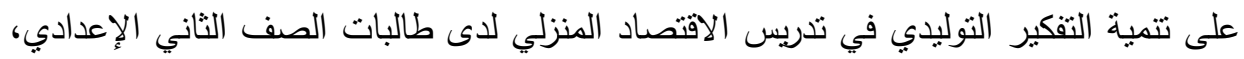

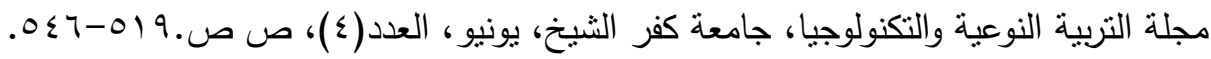

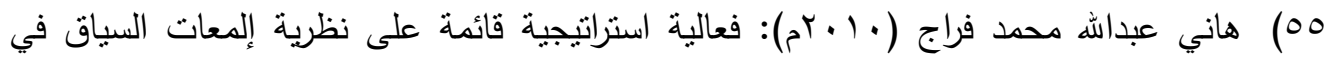
تتمية الثروة اللغوية وبعض مهارات الفهم القرائي لدى تلاميذ الصف الخامس الابتدائي، مجلة

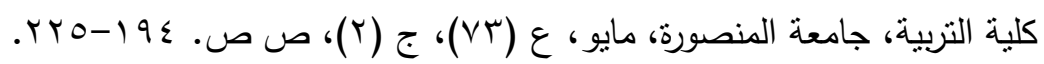

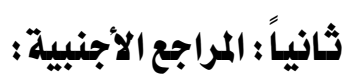

1) Bartels K, P., \& Wegener, H (2017): Doubt and excitement: an experiential learning approach to the teaching the practice of qualitative research. Journal Qualitative Research, Vols. 1468794117713056.

2) Deneen, j (2010): schools that succeed, students who achieve: profiles of programs helping all students to learn. Maryland: rodman\& Littlefield, Inc.

3) Hanuscin (2008): the impact of random excitation in the collection of the students in the fourth preparatory. Material neighborhoods. America, unpublished MA Thesis.

4) Decety, $\mathrm{j}$ (2004): the timing of mentally represented actions. Journal of research, 2 (1), pp. 120-132.

5) Tsai, K (2012): play, imagination, and creativity: A brief literature review, journal of education and learning. Vol 42(1), pp.7-97

6) Nayak A. \& Roa, V (2004): Classroom teaching: Methods and practices. New Delhi: APH publishing Corporation.

7) Sawsan Khalil Mezied (2021): the effect of random excitement strategy on developing English conversation skills among ninth graders. Islamic university of Gaza. Journal of educational and psychology sciences: Vol 29, No 4. 